\title{
GEOLOGIA DA FOLHA DE RIO CAPETINGA
}

\author{
Percy Corrêa VIEIRA *
}

\section{RESUMO}

\begin{abstract}
A Folha de Rio Capetinga (1:50000) situa-se no nordeste da Bacia Sedimentar do Paraná $\left(47^{\circ} 00^{\prime}-47^{\circ} 15^{\prime} \mathrm{W}\right.$ e $\left.22^{\circ} 00^{\prime}-22^{\circ} 15^{\prime} \mathrm{S}\right)$ no Setor Aguaiano da Zona do Moji-Guaçu, da Depressão Periférica Paulista. São encontrados, Supergrupo Tubarão: Grupo Itararé (Formação Aquidauana) e Grupo Tatuí; intrusões de diabásio; Formação Piraçununga (esta compondo mais da metade da folha) e sedimentos quaternários. As formações geológicas de Superfície autóctones são representadas pelos regolitos da Formação Aquidauana e do Grupo Tatuí, bem como pelos das intrusôes de diabásio, enquanto que as alóctones, pela Formação Piraçununga e sedimentos quaternários.
\end{abstract}

\begin{abstract}
This work deals with geological map of the Rio Capetinga topographic sheet, located in the northeastern part of the Paraná Sedimentary Basin, in the São Paulo State. There are in this area the following geologic unities: Tubarão Supergroup with Itararé Group (Aquidauana Formation) and Tatuí Group, diabase intrusions, Piraçununga Formation and quaternary sediments. It is also studied, by the granulometric aspect, the regolith which is present over the Tubarão Supergroup rocks and over the diabase intrusions. The Tubarão Supergroup rocks, Piraçununga Formation and quaternary sediments are emphasyzed by their granulometric characteristics and sedimentary processes.
\end{abstract}

\section{INTRODUÇÃO E OBJETIVOS}

O presente trabalho é produto do "Projeto de Levantamento de Formaçõ̃es Geológicas de Superfície", que está em execução no Instituto Geológico desde o ano de 1976, tendo por objetivo a edição de folhas geológicas apresentando os seguintes dados: formações geológicas de superfície autóctones e alóctones com caracterização da granulometria e espessura; levantamento estratigráfico, estrutural e dos recursos minerais.

Em 1981 foi publicada a "Folha Geológica de Rio Capetinga - Formações Geológicas de Superfície", na escala 1:50000; este trabalho tem por finalidade discutir e dissertar a folha, dando ênfase:

a) ao extenso capeamento cenozóico;

b) às diferentes características granulométricas entre as várias unidades; c) aos prováveis ambientes de deposição das mesmas, esclarecendo os mecanismos envolvidos.

A Folha de Rio Capetinga situa-se na região norte-nordeste do Estado de São Paulo (nordeste da Bacia Sedimentar do Paraná), entre os meridianos $47^{\circ} 00^{\prime}$ e $47^{\circ} 15^{\prime} \mathrm{W}$ e os paralelos $22^{\circ} 00^{\prime}$ e $22^{\circ} 15^{\prime} \mathrm{S}$. Abrange parte dos municípios de: Aguaí, Piraçununga, Leme, Moji-Guaçu e Araras. Sua área é de 712 quilômetros quadrados (Figura 1).

\section{METODOLOGIA}

Constituiu-se de:

a) Interpretação aerofotogeológica e de imagens do Satélite Landsat, com base nas técnicas convencionais;

* Instituto Geológico - Caixa Postal 8772 - 01000 - São Paulo, SP, Brasil.

Recebido para publicação em abril de 1983. 
b) levantamento geológico de campo com uso das técnicas habituais, além de:

\section{b.1 execução de furos a trado ma- nual para caracterização, medi- ção da espessura e coleta de amostras da formação geológica de superfície, bem como conhe- cimento da formação geológica basal;}

b. 2 estudo granulométrico expedito. Devido à dificuldade de mapeamento de certas porções do Supergrupo Tubarão e da Formação Piraçununga, cujas características visuais eram bastante semelhantes, conhecidas as características granulométricas de partes típicas dessas unidades, utilizou-se no campo da peneira com abertura de 0,088 milímetros já que as de menor abertura não se mostraram propícias ao peneiramento manual. Pesados, desagregados e peneirados cem gramas da amostra, quando o fundo continha menos de vinte gramas, tratava-se da Formação Piraçununga; se mais de trinta gramas, Supergrupo Tubarão; entre essas duas massas a uniclade não ficava caracterizada;

c) controle sistemático de rochas sedimentares e formações de superfície através de análises granulométricas convencionais, com construção de curvas de frequiência acumulada, cálculo dos parâmetros de FOLK \& WARD, bem como análise estatística e interpretação geológica dos dados.

\section{LEVANTAMENTOS GEOLÓGICOS ANTERIORES}

SÃO PAULO. INSTITUTO GEOGRÃFICO E GEOLÓGICO — IGG (1965) apresentou a Folha Geológica Provisória de Araras, na escala 1:100000 que, nesta região mostra predominância absoluta do Grupo Tubarão, secundado por intrusões de diabásio e sedimentos holocênicos.

PETROBRÁS, RIO DE JANEIRO (1971), na folha SF-23-M (escala 1:250000) e na folha SF-23-M-II (escala 1:100000), mapeia nesta região a Formação Aquidauana, ocupando a quase totalidade da folha; as formações, Itararé e Aquidauana, mais as formações, Palermo e Irati no extremo sudoeste; intrusões de diabásio ao nordeste, sudoeste e centro-oeste, bem como a Formação Rio Claro no centro-noroeste.

SÃO PAULO. DEPARTAMENTO DE ÁGUAS E ENERGIA ELÉTRICA (1975) apresenta em seu mapa na escala 1:250000, predominância da Formação Aquidauana/Itararé, com intrusões de diabásio. Formação Rio Claro e aluviões quaternários. No canto sudoeste aparece sobre o Aquidauana/Itararé e sob diabásio, um corpo constituído pelas formações, Tatuí, Irati e talvez Estrada Nova.

BRASIL. DEPARTAMENTO NACIONAL DA PRODUÇÃO MINERAL (CONVENIO DNPM-CPRM) (1977), PROJETO SAPUCAI, apresenta na Folha de Campinas (SF-23-Y-A), escala 1:250000, nesta região, predominância da Formação Aquidauana/Itararé, com corpos diabásicos intrusivos, Formação Rio Claro, aluviões quaternários e no canto sudoeste a Formação Tatuí inferior e superior, acima do Aquidauana; sobre ela a Formação Irati, sotoposta a diabásio.

COTTAS et alii (1981) apresentam mapa na escala 1:400000, através de mapeamento sistemático feito na escala 1:50000, mostrando nesta área a Associação Litológica Itararé I (ambiente flúvio-glacial), do Subgrupo Itararé, interdigitada com o - Membro Rio Capetinga, da Formação Aquidauana (Grupo Tubarão), depositado em ambiente flúvio-lacustre. Essas unidades ocupam as zonas, nordeste, centro-leste e sul. No extremo sudoeste aparece a Formação Tatuí. Corpos intrusivos básicos aparecem nas porções, centro-oeste e nordeste. Extenso capeamento cenozóico perfaz as regiões, noroeste, nordeste, central, sudoeste, leste e sul. São mapeadas amplas falhas de direção noroeste, aparecendo outras menos abundantes nas direções, lesteoeste, norte-sul e sudeste.

SÃO PAULO. DEPARTAMENTO DE ÁGUAS E ENERGIA ELETTRICA UNIVERSIDADE ESTADUAL JULIO DE MESQUITA FILHO (CONVENIO) (1981), com compilação de levantamentos geológicos ainda inédita, escala 1:250000, 


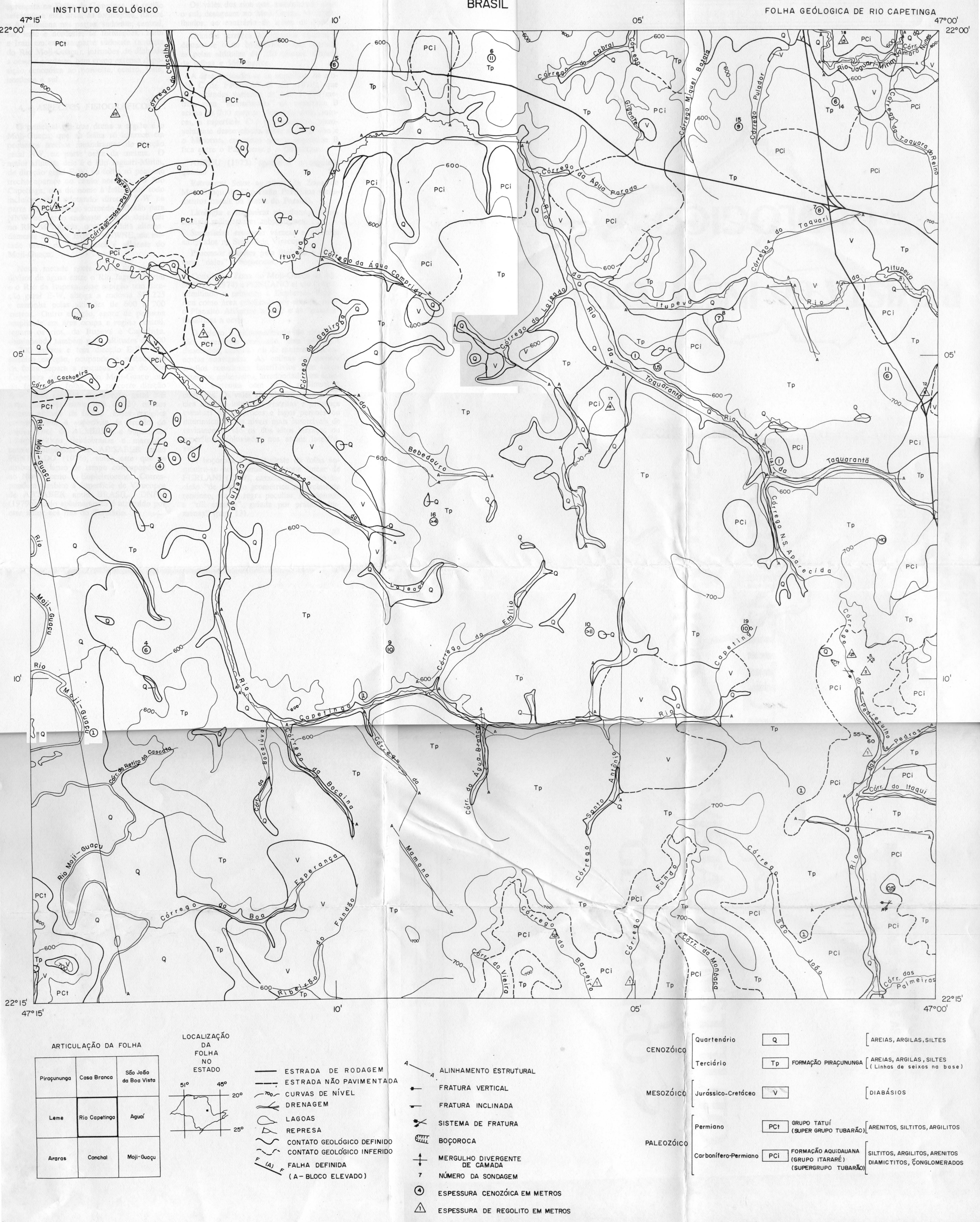


apresenta na Folha de Campinas, na região referente a esta área, as formações, Itararé e Aquidauana nas partes, sudoeste, central, sul, leste e nordeste; as formações, Tatuí e Irati em estreita parte sudoeste (a oeste do Rio Moji-Guaçu); intrusões de diabásio a oeste e nordeste, bem como extensa deposição cenozóica ao noroeste, centro, leste, nordeste e sul.

\section{ASPECTOS FISIOGRÁFICOS}

O principal rio que drena a região é o Moji-Guaçu, que na folha só aparece em pequenos trechos meandrantes de direção geral NW, na parte oeste da mesma. O maior afluente dele é o Rio Jaguari-Mirim, de direção geral E-W; na folha só pequeno trecho aparece no canto nordeste. O Rio Capetinga, que dá nome à folha, está todo incluído nela, adotando direção $\mathrm{E}-\mathrm{W}$ na parte sul da mesma, sofrendo inflexão para NNW no canto sudoeste e indo desaguar no Rio da Itupeva, o qual adota alternadamente direções E-W e NNWNE, na metade norte da folha; este é afluente do Moji-Guaçu.

Nessa metade norte existe um espigão divisor de águas entre o Rio Jaguari-Mirim e o Rio da Itupeva, esse espigão tem direção geral E-W, abriga a rodovia SP 225 e caminha pelas altitudes de 600 a 700 metros. Outro espigão, agora de pequena amplitude em área ocupa a região central, separa os rios, da Itupeva e Capetinga, caminhando também pelas altitudes de 600 a 700 metros e tem direção E-W. Um terceiro espigão, ocupando a metade sul da folha separa a pequena bacia do Rio Capetinga da grande do Moji-Guaçu onde, fora desta folha, ele percorre direção $\mathrm{E}-\mathrm{W}$; esse espigão, de direção geral NE toma altitudes entre 640 e 730 metros (maior altitude da folha). Esses espigões correspondem à superfície de erosão do médio Tietê de ALMEIDA e Superfícies Interplanálticas desdobradas e marcadamente poligênicas de AB'SABER apud PENTEADO (1976), autor este que as atribui ao lapso de tempo correspondente ao Neoplioceno e Eopleistoceno. Correspondem também à Superfície de Viracopos de AB'SABER apud BRASIL. DNPM (1979b), cujo aplainamento é atribuído por esse autor aos fins do Terciário.
Os vales dos rios que, caminhando para o sul, desaguam no Moji-Guaçu, são entalhados, ao contrário de todos os demais.

Grandes terraços holocênicos existem e destaca-se o do Moji-Guaçu que espraiase pelas altitudes de 550 (menor altitude da folha) e 566 metros.

A área enquadra-se na superfície de erosão C de FREITAS et alii (1979), que tem altitudes variando de 540 a 670 metros, com "monadnocks" da superfície B acima de 700 metros. Segundo esses autores, a superfície $\mathrm{C}$ é pós eocênica, possivelmente desenvolvida entre o Oligoceno e o Mioceno, enquanto que a superfície B fica entre o Paleoceno e o Oligoceno.

ABREU (1973) apresenta o seguinte
quadro:

Estrutura: Setor aguaiano da Zona do Moji-Guaçu da Depressão Periférica (sedimentos basais da Bacia do Paraná).

Litologia e tectônica: plataformas interfluviais sedimentares tabuliformes.

Superfícies erosivas: várzeas e alvéolos embutidos na Superfície Viracopos.

Processos guiados pela litologia e estrutura: "dales" e boçorocas.

Constitui a Zona do Moji-Guaçu de ALMEIDA (1974) e PONÇANO et alii (1980), admitindo o primeiro a Depressão Periférica como área rebaixada por erosão, entre o Planalto Atlântico a leste e as "cuestas" basálticas a oeste.

O relevo é principalmente de degradação, levemente ondulado, com planaltos dissecados, colinoso ou de morros com encostas suavizadas. As colinas ou morros amplos constituem interflúvios com topos extensos, aplainados, arredondados ou achatados, vertentes com perfis retilíneos a convexos. Os vales são abertos, com planícies aluviais interiores restritas e presença eventual de boçorocas e lagos perenes ou intermitentes. Os níveis mais suscetíveis de ravinamento são os dos altos terraços ou superfícies coluviadas nos atuais interflúvios.

A boçoroca a este-sudeste da folha enquadra-se no sistema de forma linear de FURLANI (1969), caracterizada como incisão "de traçado geométrico notavelmente retilíneo, via de regra peculiar, relacionada a "rill erosion", guiada por práticas humanas" (pág. 13). 
A drenagem é de baixa densidade e apresenta um padrão misto entre retangular e dendrítico, retangular nos rios principais e dendrítico nos menores.

O Rio Moji-Guaçu é subseqüente, acompanhando uma direção de alinhamento estrutural NW, o mesmo se dá com o trecho médio-baixo do Rio Capetinga. $\mathrm{O}$ trecho alto-médio deste rio é consequiente. Os rios, Jaguari-Mirim e da Itupeva apresentam trechos subseqüentes e conseqüentes. Todos esses fatos denotam forte influência estrutural no desenvolvimento hidrográfico.

\section{GEOLOGIA}

A Folha de Rio Capetinga compõe-se das seguintes unidades geológicas: Supergrupo Tubarão, com Grupo Itararé (Formação Aquidauana) e Grupo Tatuí; intrusões de diabásio; Formação Piraçununga e sedimentos quaternários. A Formação Aquidauana aflora em 90 quilômetros quadrados (cerca de 12,7\% da área total), o Grupo Tatuí em 38 quilômetros quadrados (cerca de $5,3 \%$ ), as intrusões de diabásio em 37 quilômetros quadrados (cerca de $5,2 \%$ ), os sedimentos provavelmente terciários (Formação Piraçununga) em 465 quilômetros quadrados (cerca de $65,3 \%$ ) e os sedimentos quaternários em 82 quilômetros quadrados (cerca de 11,5\%) (Figura 1).

\subsection{Grupo Itararé (Formação Aquidauana)}

A primeira referência aos arenitos desta formação foi feita por DERBY em 1890 apud BRASIL. DNPM (1979a). O nome Aquidauana foi utilizado pela primeira vez por ARROJADO LISBOA em 1909 apud FIORI \& LANDIM (1980) para designar sedimentos vermelhos que ocorrem no flanco oeste da Bacia do Paraná, no vale do Rio Aquidauana, Estado de Mato Grosso do Sul, indicando como seção tipo aquela atravessada pela Estrada de Ferro Noroeste do Brasil, nesse mesmo vale. OLIVEIRA em 1916 apud BRASIL. DNPM (1979a) notou equivalência dos sedimentos carboníferos do Estado de São Paulo com os que ARROJADO LISBOA houvera chamado de Aquidauana.

ALMEIDA \& BARBOSA (1953) e ALMEIDA (1954) foram os primeiros autores a correlacionar sedimentos do flanco leste da Bacia a essa formação, dizendo este último à pág. 71: "Mais tarde foi-nos possível reconhecer a extensão da série Aquidauana ao interior do Estado de São Paulo, onde atinge pelo menos a região de Casa Branca".

$\mathrm{Na}$ área da Folha de Rio Capetinga, a Formação Aquidauana assenta-se discordantemente sobre o embasamento cristalino, através de superfície irregular. FREITAS (1953) sugere uma fase grandemente erosiva atuando nos sedimentos devonianos, o que justificaria a deposição direta do permo-carbonífero sobre o embasamento cristalino em grandes porções da Bacia do Paraná; corresponde à superfície de erosão Itaguá de ALMEIDA (1974). FÚLFARO (1971) entretanto crê que o Grupo Paraná não atingiu esta parte do Estado. O contato Aquidauana-Cristalino é aflorante nas folhas de Aguaí e São João da Boa Vista, a leste e nordeste respectivamente.

Essa formação compõe-se de siltitos argilosos, siltitos arenosos, arenitos sílticos, argilitos sílticos, siltitos, arenitos argilosos, siltitos argilo-arenosos, diamictitos e conglomerados, de cores, chocolate, vermelha e marrom, variegadas de branco, amarelo e cinza. As estruturas sedimentares encontradas são a compacta, a acamada plano-paralelamente e a lenticular, com grande variação faciológica.

\subsection{Grupo Tatuí}

O nome Formação Tatuí foi proposto por WASHBURNE (1930). Esse grupo aflora na parte oeste da folha e constitui-se de arenitos sílticos e siltitos argilosos de cores, chocolate a branco ou cinza claro. As estruturas sedimentares são a compacta e a acamada.

Não pôde ser observada a superfície de descontinuidade na sedimentação na base do Tatuí, indicativa de quebra de registro estratigráfico, conforme proposto por SOARES (1972) e SOARES et alii (1978). Para o primeiro autor esse contato separa um pacote de sedimentos essencialmente sílticos, com calcários e sílex, de outro predominantemente arenoso e com diamictitos, o que significa a separação de um ambiente de baixa energia (Tatuí) de outro de alta energia (Itararé). Diz ainda esse autor que esse limite é uma discordância, cuja interpretação baseia-se na presença de superfície de erosão irregular 
e conglomerado basal, este de ocorrência descontínua; define o limite entre os ciclos, glacial e pós glacial, no centro-leste de São Paulo.

A ocorrência do Grupo Tatuí apenas na parte oeste da folha pode mostrar o embaciamento nesse sentido, pode ser um registro do levantamento meso-cenozóico do leste, com erosão da borda da bacia ou pode finalmente significar ambas as coisas.

\subsection{Intrusões de diabásio}

Predominam as do tipo lacólito. Em alguns casos os contatos com outras formações são percorridos por rios, os quais certamente acompanham direções de fraqueza caracterizadas pelo contato litológico, pela dificuldade de escavar as rochas ígneas mais duras.

As intrusões ígneas compõem-se de diabásios às vezes compactos, mas geralmente fraturados em blocos com esfoliação esferoidal ou disjunção colunar. A cor é cinza-escuro a preta, com textura fanerítica, granulação fina a média. Estão geralmente alterados, formando terra roxa.

A distribuição é irregular, os tamanhos e formas geométricas dos afloramentos também, as altitudes de ocorrências variam desde menos de 600 até pouco menos de 700 metros na quase totalidade da folha (margem direita do Rio Moji-Guaçu) e pouco mais de 700 metros na margem esquerda (área sudoeste). Não há dados de espessura.

\subsection{Formação Piraçununga}

Constitui-se de sedimentos areno-argilosos e areias com muito pouco silte (média de 5 e máximo de $18 \%$ ), pobremente a muito pobremente selecionados, sem estruturas sedimentares bem definidas, verticalmente homogêneos assemelhando-se a solos, cores do vermelho ao amarelo, grãos de quartzo com vários graus de arredondamento, às vezes com película de óxido de ferro secundário e poucos minerais máficos. As espessuras variam desde menos de um metro até cerca de onze metros, sendo afossilíferas.

Essa formação foi definida e descrita por FREITAS et alii (1979), que dizem à pág. 267: "A montante desses acidentes tectônicos (horsts) houve grandes planícies de inundação, onde se depositou a Forma- ção Piraçununga, nome este dado a um conjunto de sedimentos argilo-arenosos e cascalhos. O clima era úmido e tropical, documentado pela textura areno-argilosa dos sedimentos e pela seletividade química operada nos seixos, pois são compostos exclusivamente de quartzito e quartzo (Eoceno)".

Na Folha de Rio Capetinga ela alcança sua maior extensão com relação a todas as folhas adjacentes já levantadas no Projeto. Já WOHLERS (1964) lembrava da necessidade de ampliar a extensão dos depósitos cenozóicos no Estado, citando o vale do Rio Moji-Guaçu ao norte de Conchal como área cenozóica.

Assenta-se em superfície erosiva plana ou ondulada, horizontal ou inclinada das unidades mais antigas, em alguns locais iniciando por linha de seixos ou cascalheira de poucos centímetros de espessura, constituídas por seixos de quartzo geralmente arredondados, ora semi esféricos, ora achatados, muitas vezes soldados por cimento limonítico. Também foi encontrada linha de seixos formada por fragmentos do Supergrupo Tubarão endurecidos pelo mesmo cimento limonítico. Não existe recorrência das mesmas. Talvez se trate (no caso das cascalheiras), de depósitos do tipo "point-bar", formados por migração lateral de canais, ou de planícies de inundação. Trata-se pois de sedimentos provavelmente fluviais.

Este autor entende que a constituição de parte dessa formação só foi possível graças ao papel de soleiras representado pelos basaltos, que estabeleceram níveis de base locais durante períodos suficientemente longos para deixar extensas áreas sob regime de agradação e coluviação. SOARES \& LANDIM (1973) admitem que esses sedimentos cenozóicos têm sua origem no Ciclo Velhas (Quaternário), o qual deixou depósitos embutidos na Depressão Periférica, sob a forma de terraços ou espigões tabuliformes, cuja permanência sobre espigões se dá devido à fraca competência da drenagem em superfícies pouco inclinadas. SOARES \& LANDIM (1976) correlacionam os depósitos de 590 a 700 metros de altitude aos de Campinas (Aeroporto de Viracopos), Moji-Mirim, Casa Branca, Limeira, Piraçununga, Rio Claro e Ajapi (Superfície dos médios interflúvios) e citam a existência de baixos terraços a 40-60 metros acima do nível local dos rios em 
Piraçununga, no vale do Rio Moji-Guaçu, além de terraços menores entre 5 e 15 metros acima do nível local dos rios. Todos esses depósitos, segundo os autores, são correspondentes ao soerguimento neogênico do Quaternário.

Conquanto AB'SABER apud MODENESI (1974a) admita a elaboração dos aplainamentos neogênicos por processos de pedimentação combinados com sistema de drenagem exorreica intermitente, prefere-se aqui adotar a hipótese de PENTEADO (1976) a favor da deposição ao longo de canais fluviais, isto por que não se pode explicar um espessamento grande e generalizado em superfície admitindo-se condições de escoamento exorreico, já que assim os altos topográficos (interflúvios) teriam cobertura detrítica mais delgada ou ausente e é exatamente o contrário que se verifica.

Esses sedimentos cenozóicos são de ocorrência ampla, apresentando muita extensão em superfície e pouca em profundidade, com as seguintes características: presença de pequenas lagoas circulares e depressões fechadas, baixa densidade de drenagem, tonalidades claras do terreno; colinas amplas e com perfil convexo, presença de boçorocas nas frentes de erosão, cobertura vegetal rala do tipo cerrado.

\subsection{Sedimentos quaternários}

Compõem-se de depósitos pouco espessos, formados por areias argilosas, areias sílticas, areias, areias síltico argilosas, argilas síltico arenosas e argilas sílticas, sem estruturas sedimentares, com cores desde o cinza escuro ao amarelado, localizados nos talvegues e várzeas dos rios, provenientes não só de montante pelo transporte fluvial, como também das vertentes por transporte coluvial. As espessuras são sempre menores que um metro, com exceção do terraço do Rio Moji-Guaçu, onde elas ultrapassam de pouco essa medida.

Vários desses depósitos são formados a partir de barreiras naturais formadas por diabásio; como exemplo disso têm-se os rios, da Itupeva e Capetinga, bem como seus afluentes.

Um fato interessante é a existência de sedimentação quaternária em cabeceiras de rios, o que é causado por coluviação local ou retomada de erosão a jusante.

\section{FORMAÇÕES GEOLÓGICAS DE SUPERFICIE}

No decurso da ação dos processos de intemperismo e/ou erosão e deposição, as rochas sofrem incessantes modificações decorrentes de sua alteração, transformação e remanejamento, dando como produto, materiais secundários, muitas vezes diferentes daqueles que lhes deram origem. Esse tipo de cobertura superficial praticamente contínua sobre os continentes constitui para DEWOLF apud GONÇALVES (1978) as chamadas formações superficiais (aqui denominadas de formações geológicas de superfície). Naturalmente essas formações são sempre suportadas por um substrato, podendo elas ser ou não derivadas dele. No primeiro caso temos o substrato ativo (substrato-origem), com formações geológicas de superfície evoluídas "in situ" e por isso mesmo chamadas de autóctones, por estarem geneticamente relacionadas a ele; no segundo caso o substrato é passivo (substrato-suporte), servindo de embasamento sobre o qual jazem formações geológicas de superfície que lhe são independentes, denominadas alóctones, depositadas na superfície do mesmo por processos de remanejamento e transporte.

No complexo de agentes de formações geológicas de superfície entram fatores morfoclimáticos e estruturais responsáveis pela evolução e aspectos apresentados pela paisagem. Assim estabelecem-se correlações entre essas formações, formas de relevo e suas posições ocupadas na paisagem.

Na Folha de Rio Capetinga o substrato, quer ativo ou passivo, é representado pela Formação Aquidauana e o Grupo Tatuí, bem como por intrusões de diabásio, predominando a Formação Aquidauana.

Constituem maioria as formações geológicas de superfície alóctones cenozóicas, as quais espraiam-se por todas as partes da região, com espessuras medidas desde 0,5 até 11 metros (indicadas na Figura 1 por círculos). Ocupam todas as posições topográficas, desḑe espigões, meias encostas, vales e baixios.

As formações geológicas de superfície autóctones são de menor ocorrência, constituídas por regolitos pouco espessos $(0,5$ a 3 metros), às vezes alcançando os 11 metros (indicadas na Figura 1 por triângu- 
los). Ocupam também todas as posições topográficas. Formam corpos isolados, espalhados por toda a folha.

Algumas dessas porções não são de fácil identificação, como é o caso de diabásios cujos solos apresentam contribuição de grãos de quartzo detrítico, como também do Aquidauana de algumas porções, onde nem sempre é fácil a distinção com outras formações. A respeito pronuncia-se GONÇALVES (1978) pág. 80: "Sabe-se que, para solos desenvolvidos sobre rochas básicas, os mais diversos procedimentos de caracterização granulométrica ainda não atingiram uma reprodutibilidade de resultados perfeitos, tendo em vista os aspectos micromorfológicos inerentes ao próprio material ...". "Essa observação poderia explicar as porcentagens um tanto elevadas de silte e até de areia existente em determinadas amostras, principalmente naquelas de textura argilosa". (...). "... comprova a presença indiscutível de quartzo em quantidades tão apreciáveis que sobrepujam aquelas normalmente esperadas do acúmulo de quartzo residual de rochas básicas. Trata-se de quartzo alógeno, proveniente das formações sedimentares arenosas locais...".

FULFARO (1979) chama de "Sedimentos inconsolidados, 'assemelhando-se a solos, com nível de seixos na base", os depósitos que aqui estão atribuídos à Formação Piraçununga, que são inconsolidados, confundíveis com solos, recobrindo discordantemente outros tipos litológ:cos. O contato com as rochas subjacentes é feito através de uma superfície erosiva irregular, de desnível variado, sotoposta muitas vezes a cascalhos, com seixos de sílex, quartzo e fragmentos de limonita. Encontram-se freqüentemente recobrindo os espigões ou preenchendo páleo vales escavados em rochas mais antigas. Diz esse autor à pág. 234: "É difícil, no atual estágio de conhecimento desses depósitos inconsolidados, estabelecer uma gênese e cronologia únicas. Pode-se dividi-los, pelas suas áreas de ocorrência, em pelo menos três tịpos: a) Depósitos de espigão; b) Depósitos frontais a escarpas regionais (pedimentos); c) Depósitos em páleo-vale".

O mesmo autor chama de "Depósitos fluviais atuais" os sedimentos que denominamos de quaternários. Eles são pouco significativos, já que a Bacia do Paraná mostra evidências de levantamento genera- lizado, com grandes rios encontrando-se em regime de "by passing". $O$ balanço erosão/sedimentação da drenagem da bacia mostra somente aspectos de manutenção dos perfis longitudinais de seus rios. Isso pode ser ilustrado pela fragilidade dos divisores de águas. Esses depósitos são devidos em parte a barreiras resistentes naturais, como corpos de diabásio ou pela implantação de inúmeras barragens.

Tudo indica que a homogeneidade litológica das formações geológicas de superfície reflete o caráter do material original, mesmo no caso de ter havido remanejamento e transporte em função principalmente da topografia oferecida pelo relevo, o que teria proporcionado deposição em maior ou menor proximidade do substrato. É pois possível que um mesmo substrato tenha desempenhado o duplo papel de origem e suporte para o material de cobertura.

Como já foi dito, com freqüência verifica-se sob as formações geológicas de superfície alóctones tidas como terciárias, a existência de um horizonte inferior de seixos ("stone lines"). A maioria dos autores brasileiros interpreta-o como originário de ação climática do tipo seco com processos de transporte ocorridos em clima mais úmido, os quais originariam também os materiais de recobrimento. Situa-se geralmente no limite da formação alóctone com o regolito (formação autóctone); ocorre quase sempre de forma descontínua e interrompida. Em alguns casos acompanha subsuperficialmente a topografia atual. Não foram encontradas linhas de seixos sobrepostas.

Nas superfícies de erosão mais antigas e elevadas encontram-se as formações geológicas de superfície mais espessas, talvez provenientes do retrabalhamento das próprias rochas circunvizinhas. Não são raras também as ocorrências de "stone lines" com restos de bancadas ferruginosas, misturadas a seixos de quartzo, representando verdadeiras discordâncias erosivas com os materiais subjacentes.

Também merecem destaque as formações mais rasas localizadas nas quebras de gradientes e as formações aluviais, nos vales atuais. MODENESI (1974b), às págs. 243 e 244 afirma: "As formações superficiais de vertente opõem-se às de topo, por uma série de características. De um modo geral, são menos espessas, principalmente nas altas e 
médias vertentes". (...). "Resultam de uma evolução posterior às fases de entalhamento do relevo, responsáveis pela remoção dos materiais pré-existentes. Apesar de a maioria apresentar linhas de seixos basal, há maior relação entre o recobrimento e a rocha subjacente, evidência de retrabalhamento curto".

A unidade alóctone mais antiga apresenta-se recobrindo espigões, correspondendo a depósitos residuais associados à mais antiga superfície de erosão preservada, do Terciário. Unidades mais recentes (embora supostamente ainda terciárias) ocorrem em patamares associados aos principais vales ou às principais escarpas.

Assim como MODENESI (1974a), podem-se considerar em relação à posição topográfica, quatro tipos de depósitos de superfície: 1 - formações de topo, que recobrem os níveis topográficos; 2 - formações de vertente; 3 - rampas de colúvio e 4 - terraços fluviais.

\section{ANÁLISES GRANULOMETRICAS}

\subsection{Controle granulométrico}

O "Projeto de Levantamento de Formações Geológicas de Superfície" utiliza como método o estudo sedimentológico; até esta altura só pôde ser levado a efeito o controle granulométrico. Foram analisadas rochas do Supergrupo Tubarão (Formação Aquidauana e Grupo Tatuí), regolitos do Supergrupo Tubarão, regolitos de diabásio, sedimentos da Formação Piraçununga e sedimentos quaternários. Foi utilizado o papel gráfico com escala de probabilidade aritmética para as percentagens de massa e escala $\varnothing$ (fi) para as granulometrias. Os parâmetros calculados são de FOLK \& WARD.

Foram tratadas 16 amostras da Formação Aquidauana (citadas na Figura 5); 3 do Grupo Tatuí (citadas na Figura 6) (exceção da amostra n. $\left.{ }^{0} 14\right) ; 37$ da Formação Piraçununga (citadas na Figura 7); 16 dos sedimentos quaternários (citadas na Figura 8); 30 do regolito da Formação Aquidauana (citadas na Figura 9); 5 do regolito do Grupo Tatuí (citadas na Figura 10) e 14 do regolito de diabásio (citadas na Figura 11).

\subsubsection{Diagramas triangulares}

A Figura 2 mostra que:

I - a Formação Aquidauana e o Grupo Tatuí são os mais ricos em silte, chegando algumas amostras a ultrapassar os $70 \%$;

II - a Formação Piraçununga possui um posicionamento bem definido, composto por aglutinação de amostras próximas ao máximo da fração areia. É particularmente pobre em silte (não ultrapassando os $18 \%$ ) e pobre em argila, cuja média não ultrapassa os $30 \%$ e cujo máximo é de $44 \%$.

III - os sedimentos quaternários são mais ricos em areia do que outras frações, entretanto mais providos de silte que a Formação Piraçununga. Excepcionalmente uma amostra (n. ${ }^{\circ}$ 86) não chega a possuir $2 \%$ de areia.

Conclui-se que não há distinção entre a Formação Aquidauana e o Grupo Tatuí (embora este esteja sendo avaliado com pequeno número de amostras), entretanto o Supergrupo Tubarão como um todo, a Formação Piraçununga e os sedimentos quaternários possuem, cada um, posições bem distintas quanto à granulometria.

A Figura 3 mostra que:

I - os regolitos, da Formação Aquidauana e do Grupo Tatuí são em parte mais arenosos que os de diabásio;

II - pequena parte dos regolitos desse Supergrupo é mais siltosa que os diabásios e outra pequena porção é até mais argilosa;

III — os regolitos de diabásio são mais argilosos que arenosos e pouco providos de silte (máximo de $33 \%$ ).

Conclui-se que não há grande distinção entre os regolitos do Aquidauana e Tatuí, a não ser que o Aquidauana apresenta maior espalhamento, isto é, contém em parte mais frações areia, silte e argila que - Tatuí (isso talvez possa ser atribuído ao pequeno número de amostras Tatuí).

Os regolitos de diabásio concentram-se mais que os anteriores. 
Rev. IG, São Paulo, 3(2):23-52, jul./dez. 1982

DIAGRAMA TRIANGULAR

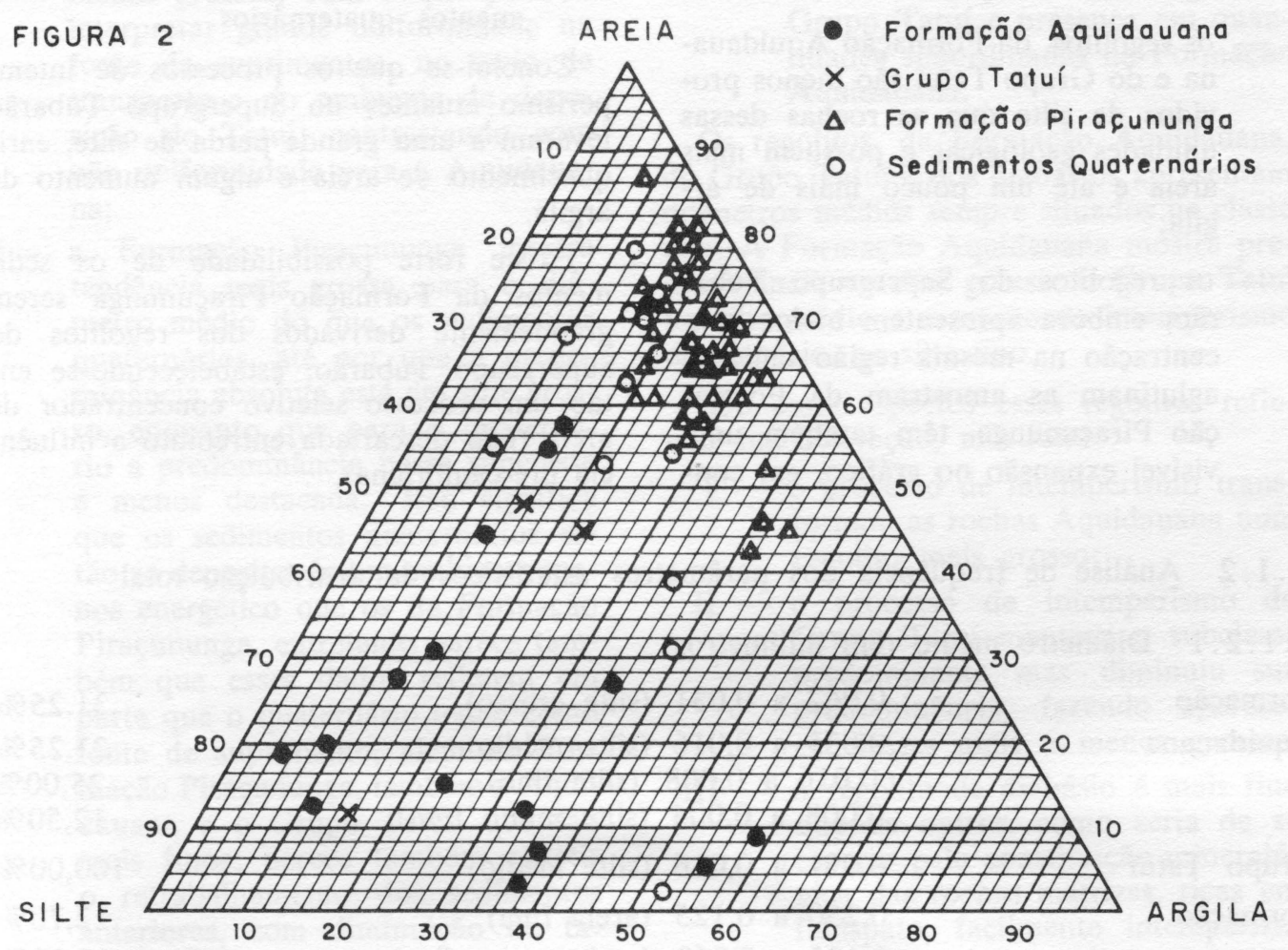

FIGURA 3

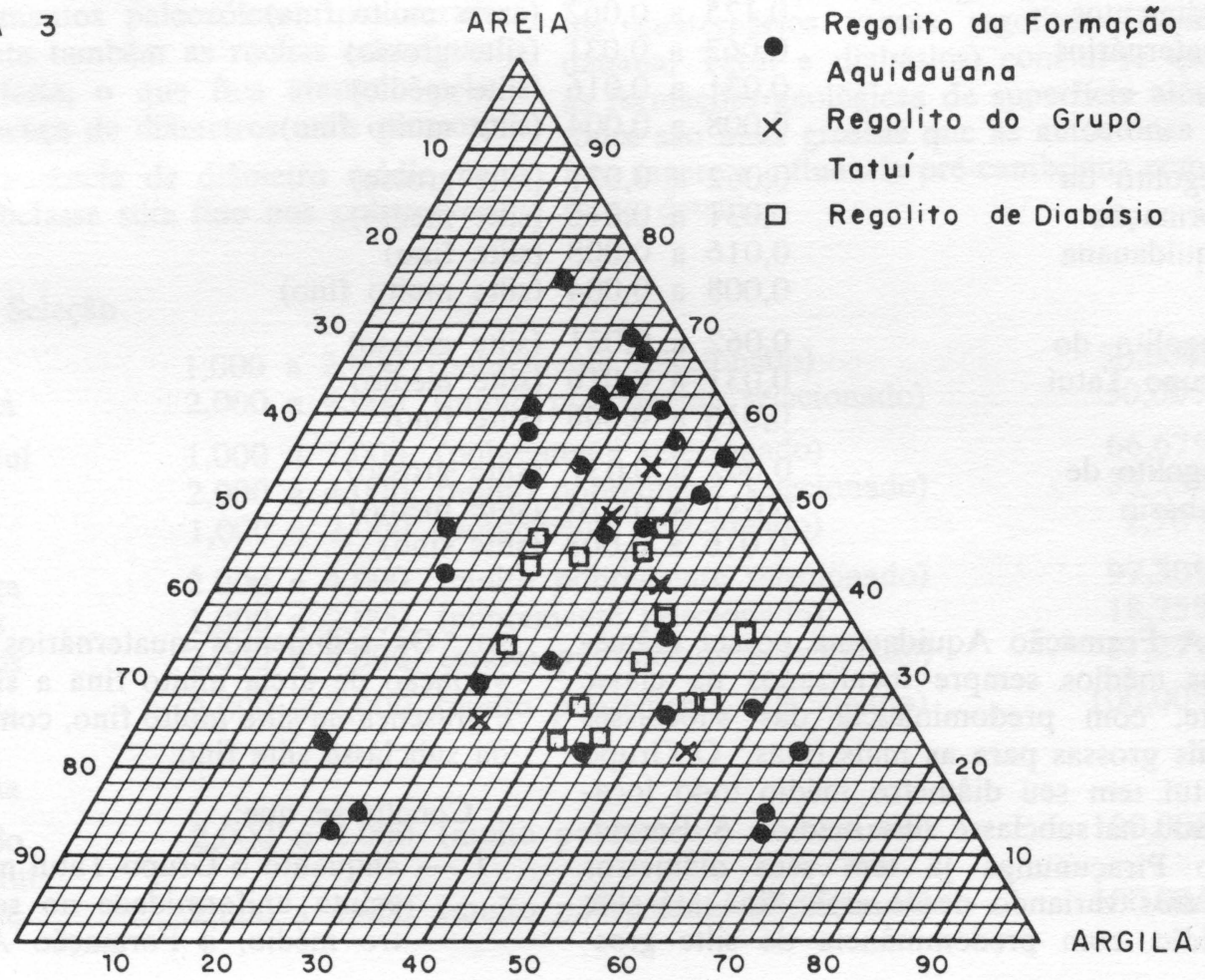


As figuras, 2 e 3 comparadas mostram que:

I - os regolitos, da Formação Aquidauana e do Grupo Tatuí são menos providos de silte que as rochas dessas unidades geológicas e possuem mais areia e até um pouco mais de argila;

II - os regolitos do Supergrupo Tubarão, embora apresentem maior concentração na mesma região onde se aglutinam as amostram da Formação Piraçununga, têm também uma visível expansão no gráfico, em con- traposição àquela formação e mesmo uma expansão maior que os sedimentos quaternários.

Conclui-se que os processos de intemperismo atuantes no Supergrupo Tubarão levaram a uma grande perda de silte, enriquecimento de areia e algum aumento de argila.

Existe forte possibilidade de os sedimentos da Formação Piraçununga serem grandemente derivados dos regolitos do Supergrupo Tubarão, estabelecendo-se então um processo seletivo concentrador de areia (não descartada entretanto a influência pré-cambriana).

\subsubsection{Análise de frequiência dos parâmetros estatísticos da distribuição total}

\subsubsection{Diâmetro médio (em milímetros)}

\begin{tabular}{|c|c|c|}
\hline Formação & 0,062 a 0,031 (silte grosso) & $31,25 \%$ \\
\hline Aquidauana & $\begin{array}{l}0,031 \text { a } 0,016 \text { (silte médio) } \\
0,016 \text { a } 0,008 \text { (silte fino) } \\
0,008 \text { a } 0,004 \text { (silte muito fino) }\end{array}$ & $\begin{array}{l}31,25 \% \\
25,00 \% \\
12,50 \%\end{array}$ \\
\hline Grupo Tatuí & 0,031 a 0,016 (silte médio) & $100,00 \%$ \\
\hline Formação & 0,250 a 0,125 (areia fina) & $2,70 \%$ \\
\hline Piraçununga & 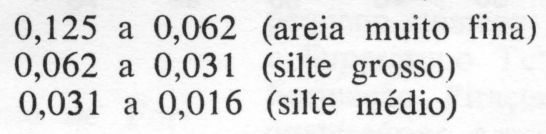 & $\begin{array}{r}18,92 \% \\
70,27 \% \\
8,11 \%\end{array}$ \\
\hline $\begin{array}{l}\text { Sedimentos } \\
\text { quaternários }\end{array}$ & $\begin{array}{llll}0,125 & \text { a } & 0,062 & \text { (areia muito fina) } \\
0,062 & \text { a } 0,031 & \text { (silte grosso) } \\
0,031 & \text { a } 0,016 & \text { (silte médio) } \\
0,008 & \text { a } 0,004 & \text { (silte muito fino) }\end{array}$ & $\begin{array}{r}31,25 \% \\
50,00 \% \\
12,50 \% \\
6,25 \%\end{array}$ \\
\hline $\begin{array}{l}\text { Regolito da } \\
\text { Formação } \\
\text { Aquidauana }\end{array}$ & $\begin{array}{llll}0,062 & \text { a } & 0,031 & \text { (silte grosso) } \\
0,031 & \text { a } & 0,016 & \text { (silte médio) } \\
0,016 & \text { a } & 0,008 & \text { (silte fino) } \\
0,008 & \text { a } & 0,004 & \text { (silte muito fino) }\end{array}$ & $\begin{array}{r}43,33 \% \\
30,00 \% \\
20,00 \% \\
6,67 \%\end{array}$ \\
\hline $\begin{array}{l}\text { Regolito do } \\
\text { Grupo Tatuí }\end{array}$ & $\begin{array}{llll}0,062 & \text { a } & 0,031 & \text { (silte grosso) } \\
0,031 & \text { a } & 0,016 & \text { (silte médio) } \\
0,016 & \text { a } & 0,008 & \text { (silte fino) }\end{array}$ & $\begin{array}{l}20,00 \% \\
60,00 \% \\
20,00 \%\end{array}$ \\
\hline $\begin{array}{l}\text { Regolito de } \\
\text { diabásio }\end{array}$ & $\begin{array}{cccl}0,062 & \text { a } & 0,031 & \text { (silte grosso) } \\
0,031 \text { a } & 0,016 & \text { (silte médio) } \\
0,016 & \text { a } & 0,008 & \text { (silte fino) }\end{array}$ & $\begin{array}{r}7,14 \% \\
35,71 \% \\
57,15 \%\end{array}$ \\
\hline
\end{tabular}

A Formação Aquidauana possui diâmetros médios sempre localizados na classe silte, com predominância das subclasses mais grossas para as mais finas. O Grupo Tatuí tem seu diâmetro médio todo localizado na subclasse silte médio. A Formação Piraçununga já tem seus diâmetros médios variando desde areia fina até silte médio, com predominância do silte gros- so. Os sedimentos quaternários mostram variação de areia muito fina a silte médio e presença de silte muito fino, com ausência da subclasse silte fino.

\section{Conclui-se que:}

I - enquanto o Grupo Tatuí mostra absoluta uniformidade no seu diâmetro médio, a Formação Aquidaua- 
na já mostra variações para mais e menos grossos, com o que pode-se interpretar grande uniformidade na fonte de suprimentos, no meio de transporte e no ambiente de deposição do Tatuí, contrastando com não uniformidade para o Aquidauana;

II - a Formação Piraçununga mostra tendência mais grossa para o diâmetro médio do que os sedimentos quaternários, até por que a predominância absoluta está em silte grosso, enquanto que para o quaternário a predominância nessa subclasse é menos destacada. Isso significa que os sedimentos quaternários estão se depositando em ambiente menos energético que os da Formação Piraçununga, entretanto parece também que esses dados refletem em parte que o quaternário tenha como fonte de suprimento, além da Formação Piraçununga, também a Aquidauana e o Grupo Tatuí, que são mais finos; parece também refletir o retrabalhamento dos sedimentos anteriores, com diminuição do tamanho dos detritos;

III - a Formação Piraçununga tem como fonte de suprimento não apenas os sedimentos paleozóicos, mas certamente também as rochas cristalinas de leste, o que fica atestado pela presença de diâmetros mais grossos;

IV - a ausência de diâmetro médio na subclasse silte fino nos sedimentos quaternários é devida à sua ausência na Formação Piraçununga e no Grupo Tatuí e presença em quantidades subordinadas na Formação Aquidauana.

Os regolitos, da Formação Aquidauana, do Grupo Tatuí e dos diabásios apresentam diâmetros médios sempre situados na classe silte. A Formação Aquidauana mostra predominância no silte grosso, o Grupo Tatuí no silte médio e o manto de intemperismo de diabásio, no silte fino.

Sob esses aspectos esses regolitos refletem sua derivação, mostrando:

I - o processo de intemperismo transformou as rochas Aquidauana num regolito mais grosso;

II - o processo de intemperismo do Grupo Tatuí manteve a subclasse predominante mas diminuiu sua predominância, fazendo aparecer subclasses mais e menos grossas;

III - o regolito de diabásio é mais fino que os outros, como seria de se esperar pela constituição mineralógica das rochas matrizes, ricas em feldspato, facilmente intemperizável, passando a caulim.

$\mathrm{Na}$ comparação entre os valores obtidos para Formação Piraçununga mais sedimentos quaternários versus regolitos (Aquidauana, Tatuí e diabásios) conclui-se que as formações geológicas de superfície alóctones são mais grossas que as autóctones e isso sugere a influência pré-cambriana como fonte detrítica.

\subsubsection{Seleção}

Formação

Aquidauana

Grupo Tatuí

Formação

Piraçununga

Sedimentos quaternários

Regolito da Formação Aquidauana

Regolito do Grupo Tatuí Regolito de diabásio
1,000 a 2,000 (pobremente selecionado)

$50,00 \%$

2,000 a 4,000 (muito pobremente selecionado) $50,00 \%$

1,000 a 2,000 (pobremente selecionado)

2,000 a 4,000 (muito pobremente selecionado)

$66,67 \%$

$33,33 \%$

1,000 a 2,000 (pobremente selecionado)

$2,70 \%$

2,000 a 4,000 (muito pobremente selecionado)

$97,30 \%$

1,000 a 2,000 (pobremente selecionado)

$18,75 \%$

2,000 a 4,000 (muito pobremente selecionado)

$81,25 \%$

2,000 a 4,000 (muito pobremente selecionado)

$100,00 \%$

2,000 a 4,000 (muito pobremente selecionado)

$100,00 \%$

2,000 a 4,000 (muito pobremente selecionado)

$100,00 \%$ 
Como as granulometrias dos materiais analisados não diferem grandemente, este autor entende ser possível um estudo comparativo entre os valores médios obtidos para o desvio padrão gráfico inclusivo.

O primeiro fato que ressalta da observação é que o Grupo Tubarão e os sedimentos cenozóicos são de pobremente a muito pobremente selecionados, o que denota que os meios de transporte e os ambientes de sedimentação não foram muito seletivos. Os regolitos são todos muito probremente selecionados, o que reflete suas origens e mostra que os processos intempéricos foram capazes de produzir alterações sob esse aspecto, aumentando a disparidade nos tamanhos dos grãos.

O Grupo Tatuí é melhor selecionado que a Formação Aquidauana, os sedimentos quaternários são melhor selecionados que a Formação Piraçununga; por outro lado o Supergrupo Tubarão é melhor selecionado que o Cenozóico.
Conclui-se que:

I - os agentes de transporte e/ou ambientes de deposição do Grupo Tatuí eram mais seletivos que os da Formação Aquidauana;

II — os agentes de transporte (rios) e/ou ambientes de deposição dos sedimentos quaternários são mais seletivos do que o foram os da Formação Piraçununga;

III - os agentes de transporte e/ou ambientes de sedimentação do Supergrupo Tubarão eram mais seletivos que os dos sedimentos cenozóicos;

IV - as formações geológicas de superfície alóctones são melhor selecionadas que as autóctones, o que em parte é devido à atuação dos processos de sedimentação nas primeiras e, em parte, à perda de silte nos regolitos do Tubarão, com conseqüiente aumento das classes, areia e argila, que têm valores granulométricos mais distantes.

\subsubsection{Assimetria}

\begin{tabular}{|c|c|c|c|c|c|}
\hline $\begin{array}{l}\text { Formação } \\
\text { Aquidauana }\end{array}$ & $\begin{array}{l}\text { menor } \\
-0,30 \\
-0,10 \\
+0,10 \\
\text { maior }\end{array}$ & $\begin{array}{l}\text { que } \\
\mathrm{a} \\
\mathrm{a} \\
\mathrm{a} \\
\text { que }\end{array}$ & $\begin{array}{r}-0,30 \\
-0,10 \\
+0,10 \\
+0,30 \\
+0,30\end{array}$ & $\begin{array}{l}\text { (muito negativa) } \\
\text { (negativa) } \\
\text { (aproximadamente simétrica) } \\
\text { (positiva) } \\
\text { (muito positiva) }\end{array}$ & $\begin{array}{r}12,50 \% \\
18,75 \% \\
6,25 \% \\
31,25 \% \\
31,25 \%\end{array}$ \\
\hline Grupo Tatuí & $\begin{array}{r}+0,10 \\
\text { maior }\end{array}$ & $\begin{array}{c}\text { a } \\
\text { que }\end{array}$ & $\begin{array}{l}+0,30 \\
+0,30\end{array}$ & $\begin{array}{l}\text { (positiva) } \\
\text { (muito positiva) }\end{array}$ & $\begin{array}{l}33,33 \% \\
66,67 \%\end{array}$ \\
\hline Formação & $+0,10$ & a & $+0,30$ & (positiva) & $8,11 \%$ \\
\hline Piraçununga & maior & que & $+0,30$ & (muito positiva) & $91,89 \%$ \\
\hline $\begin{array}{l}\text { Sedimentos } \\
\text { quaternários }\end{array}$ & $\begin{array}{l}\text { menor } \\
-0,10 \\
\text { maior }\end{array}$ & $\begin{array}{l}\text { que } \\
\text { a } \\
\text { que }\end{array}$ & $\begin{array}{l}-0,30 \\
+0,10 \\
+0,30\end{array}$ & $\begin{array}{l}\text { (muito negativa) } \\
\text { (aproximadamente simétrica) } \\
\text { (muito positiva) }\end{array}$ & $\begin{array}{r}6,25 \% \\
6,25 \% \\
87,50 \%\end{array}$ \\
\hline $\begin{array}{l}\text { Regolito da } \\
\text { Formação } \\
\text { Aquidauana }\end{array}$ & $\begin{array}{l}\text { menor } \\
-0,10 \\
+0,10 \\
\text { maior }\end{array}$ & $\begin{array}{l}\text { que } \\
\text { a } \\
\text { a } \\
\text { que }\end{array}$ & $\begin{array}{l}-0,30 \\
+0,10 \\
+0,30 \\
+0,30\end{array}$ & $\begin{array}{l}\text { (muito negativa) } \\
\text { (aproximadamente simétrica) } \\
\text { (positiva) } \\
\text { (muito positiva) }\end{array}$ & $\begin{array}{r}26,67 \% \\
3,33 \% \\
3,33 \% \\
66,67 \%\end{array}$ \\
\hline $\begin{array}{l}\text { Regolito do } \\
\text { Grupo Tatuí }\end{array}$ & $\begin{array}{r}\text { menor } \\
-0,30 \\
-0,10 \\
+0,10 \\
\text { maior }\end{array}$ & $\begin{array}{l}\text { que } \\
\mathrm{a} \\
\mathrm{a} \\
\mathrm{a} \\
\text { que }\end{array}$ & $\begin{array}{l}-0,30 \\
-0,10 \\
+0,10 \\
+0,30 \\
+0,30\end{array}$ & $\begin{array}{l}\text { (muito negativa) } \\
\text { (negativa) } \\
\text { (aproximadamente simétrica) } \\
\text { (positiva) } \\
\text { (muito positiva) }\end{array}$ & $\begin{array}{l}20,00 \% \\
20,00 \% \\
20,00 \% \\
20,00 \% \\
20,00 \%\end{array}$ \\
\hline $\begin{array}{l}\text { Regolito de } \\
\text { diabásio }\end{array}$ & $\begin{array}{l}\text { menor } \\
-0,10 \\
+0,10\end{array}$ & $\begin{array}{l}\text { que } \\
\text { a } \\
\text { a }\end{array}$ & $\begin{array}{r}-0,30 \\
+0,10 \\
+0,30\end{array}$ & $\begin{array}{l}\text { (muito negativa) } \\
\text { (aproximadamente simétrica) } \\
\text { (positiva) }\end{array}$ & $\begin{array}{r}57,14 \% \\
7,15 \% \\
35,71 \%\end{array}$ \\
\hline
\end{tabular}


Os valores da assimetria gráfica inclusiva da Formação Aquidauana variam do grau de muito negativa ao de muito positiva, com predominância de valores positivos; o Grupo Tatuí e a Formação Piraçununga só apresentam valores dos graus, de positiva a muito positiva, com predominância para o último; para os sedimentos quaternários os graus são: muito negativa, aproximadamente simétrica e muito positiva, com predominância para o último. Para os regolitos, o da Formação Aquidauana apresenta os graus, muito negativa, aproximadamente simétrica, positiva e muito positiva, com predominância do último; o do Grupo Tatuí vai de muito negativa a muito positiva, com iguais percentagens; o de diabásio apresenta os graus, muito negativa, aproximadamente simétrica e positiva, com predominância do primeiro.

Conclui-se que:

I - o Grupo Tatuí apresenta maior dispersão do lado dos finos que a Formação Aquidauana e também maior fuga da distribuição normal, o que sugere deposição em ambiente mais calmo (menos energético) e mais uniforme que o daquela;

II - a Formação Piraçununga entretanto não apresenta maior dispersão do lado dos finos que os sedimentos quaternários e também maior fuga da distribuição normal, como os dados parecem mostrar; o que ocorre é que ela é predominantemente polimodal, com grande domínio das areias sobre as argilas e quase ausência de silte, o que não fica tão destacado nos sedimentos quaternários. Isso atrai os valores da assimetria gráfica inclusiva para números positivos. A quase ausência da classe silte é devida à falta de fornecimento e não de ação selecionadora;

III — os sedimentos cenozóicos não se depositaram em ambiente menos energético que os do Supergrupo Tubarão (como os dados parecem sugerir), o que ocorre é que eles ter-se-iam derivado em parte dos regolitos desse supergrupo, regolitos esses que diferem das rochasmãe pelo menor conteúdo de silte;

IV - a distribuição percentual dos graus de assimetria pelas formações geológicas de superfície (sedimentos cenozóicos e regolitos) é muito variável e não se dispõe de elementos bastantes para conceituação geológica, mesmo por que na comparação dos dados da Formação Aquidauana e seu regolito, Grupo Tatuí e seu regolito notamse grandes discrepâncias.

\subsubsection{Curtose}

Formação

Aquidauana

Grupo Tatuí

Formação

Piraçununga

Sedimentos

quaternários

Regolito da

Formação

Aquidauana menor que 0,67

0,67 a 0,90

0,90 a 1,11

1,11 a 1,50

0,90 a 1,11

1,11 a 1,50

menor que 0,67

0,67 a 0,90

1,11 a 1,50

1,50 a 3,00

menor que 0,67

0,67 a 0,90

0,90 a 1,11

1,11 a 1,50

1,50 a 3,00

menor que 0,67

0,67 a 0,90

0,90 a 1,11

1,11 a 1,50

1,50 a 3,00 (muito platicúrtica)

(platicúrtica)

(mesocúrtica)

(leptocúrtica)

(mesocúrtica)

(leptocúrtica)

(muito platicúrtica)

(platicúrtica)

(leptocúrtica)

(muito leptocúrtica)

(muito platicúrtica)

(platicúrtica)

(mesocúrtica)

(leptocúrtica)

(muito leptocúrtica)

(muito platicúrtica)

(platicúrtica)

(mesocúrtica)

(leptocúrtica)

(muito leptocúrtica)
$12,50 \%$

$43,75 \%$

$18,75 \%$

$25,00 \%$

$66,67 \%$

$33,33 \%$

$56,76 \%$

$10,81 \%$

$8,11 \%$

$24,32 \%$

$25,00 \%$

$12,50 \%$

$12,50 \%$

$37,50 \%$

$12,50 \%$

$63,33 \%$

$16,67 \%$

$10,00 \%$

$6,67 \%$

$3,33 \%$ 
Regolito do

Grupo Tatuí

Regolito de diabásio menor que 0,67 0,67 a 0,90 0,90 a 1,11 menor que 0,67 0,67 a 0,90 (muito platicúrtica)

$60,00 \%$

(platicúrtica)

(mesocúrtica)

(muito platicúrtica)

(platicúrtica)
$20,00 \%$

$20,00 \%$

$64,29 \%$

$35,71 \%$

A Formação Aquidauana apresenta curtose gráfica variando de muito platicúrtica a leptocúrtica, predominando a platicúrtica; o Grupo Tatuí mostra variação de mesocúrtica (predominante), a leptocúrtica; na Formação Piraçununga ela varia de muito platicúrtica a muito leptocúrtica, faltando a mesocúrtica e predominando a muito platicúrtica; os sedimentos quaternários têm-na oscilando de muito platicúrtica a muito leptocúrtica, predominando a leptocúrtica. Quanto aos regolitos, o da Formação Aquidauana apresenta variação de muito platicúrtica a muito leptocúrtica, predominando a primeira; o do Grupo Tatuí apresenta oscilação de muito platicúrtica a mesocúrtica, predominando a primeira e finalmente o de diabásio mostra variação de muito platicúrtica (predominante), a platicúrtica.

Conclui-se que:

I - o Grupo Tatuí apresenta distribuição menos expandida, mais concentrada em torno da tendência central e mais próxima da unimodal que a Formação Aquidauana;

II - a Formação Piraçununga e os sedimentos quaternários são predominantemente polimodais, prevalecendo esse aspecto na citada formação;

III - os sedimentos cenozóicos são em parte mais polimodais que o $\mathrm{Su}$ pergrupo Tubarão, apresentando classes modais mais separadas, especialmente a Formação Piraçununga (carência de silte) e em parte mais unimodais (também especialmente a Formação Piraçununga);

IV - os regolitos são predominantemente polimodais, apresentando-se, em ordem decrescente, os de diabásio, os do Grupo Tatuí e os da Formação Aquidauana;

$\mathrm{V}$ - quanto às formações geológicas de superfície, as autóctones são predominantemente polimodais, enquanto que as alóctones o são menos;

VI - o regolito da Formação Aquidauana é grandemente mais polimodal que a própria Formação, com as modas mais separadas e isso é devido à perda de silte no processo intempérico. Esse fato fica muito mais acentuado no processo de intemperismo do Grupo Tatuí que, de predominantemente mesocúrtica passa no regolito a predominantemente muito platicúrtica.

\subsubsection{Média dos parâmetros}

\begin{tabular}{|c|c|c|c|c|}
\hline $\begin{array}{l}\text { Formação } \\
\text { Aquidauana }\end{array}$ & diâmetro médio: & $\begin{array}{l}\text { valor médio } \\
\text { desvio padrão }\end{array}$ & $\begin{array}{l}= \\
=\end{array}$ & $\begin{array}{l}5,7699 \\
1,0387\end{array} \varnothing$ \\
\hline & desvio padrão: & $\begin{array}{l}\text { valor médio } \\
\text { desvio padrão }\end{array}$ & $\begin{array}{l}= \\
=\end{array}$ & $\begin{array}{l}1,9997 \\
0,3527\end{array}$ \\
\hline & assimetria: & $\begin{array}{l}\text { valor médio } \\
\text { desvio padrão }\end{array}$ & $\begin{array}{l}= \\
=\end{array}$ & $\begin{array}{l}0,1511 \\
0,3918\end{array}$ \\
\hline & curtose: & $\begin{array}{r}\text { valor médio } \\
\text { desvio padrão }\end{array}$ & $\begin{array}{l}= \\
=\end{array}$ & $\begin{array}{l}0,9242 \\
0,2229\end{array}$ \\
\hline $\begin{array}{l}\text { Grupo } \\
\text { Tatuí }\end{array}$ & diâmetro médio: & $\begin{array}{l}\text { valor médio } \\
\text { desvio padrão }\end{array}$ & $\begin{array}{l}= \\
=\end{array}$ & 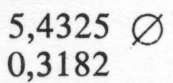 \\
\hline & desvio padrão: & $\begin{array}{l}\text { valor médio } \\
\text { desvio padrão }\end{array}$ & $\begin{array}{l}= \\
=\end{array}$ & $\begin{array}{l}1,9278 \\
0,2497\end{array}$ \\
\hline & assimetria: & $\begin{array}{l}\text { valor médio } \\
\text { desvio padrão }\end{array}$ & $\begin{array}{l}= \\
=\end{array}$ & $\begin{array}{l}0,5128 \\
0,2234\end{array}$ \\
\hline & curtose: & $\begin{array}{r}\text { valor médio } \\
\text { desvio padrão }\end{array}$ & $\begin{array}{l}= \\
=\end{array}$ & $\begin{array}{l}1,0956 \\
0,2194\end{array}$ \\
\hline
\end{tabular}


Formação

Piraçununga

Sedimentos quaternários

Regolito da Formação

Aquidauana

Regolito do

Grupo Tatuí

Regolito de diabásio

(os dados não foram tratados)

$$
\begin{aligned}
& \text { diâmetro médio: } \quad \text { valor médio }=4,4506 \varnothing \\
& \text { desvio padrão }=1,0951 \\
& \text { desvio padrão: valor médio }=2,5386 \\
& \text { desvio padrão }=0,4195 \\
& \text { assimetria: } \quad \text { valor médio }=0,5050 \\
& \text { desvio padrão }=0,3049 \\
& \text { curtose: } \quad \text { valor médio }=1,0758 \\
& \text { desvio padrão }=0,3944 \\
& \text { diâmetro médio: valor médio }=5,4274 \varnothing \\
& \text { desvio padrão }=0,9976 \\
& \text { desvio padrão: valor médio }=2,6900 \\
& \text { desvio padrão }=0,2717 \\
& \text { assimetria: } \quad \text { valor médio }=0,2036 \\
& \text { desvio padrão }=0,5002 \\
& \text { curtose: } \quad \text { valor médio }=0,7207 \\
& \text { desvio padrão }=0,2736 \\
& \text { diâmetro médio: } \quad \text { valor médio }=5,6441 \varnothing \\
& \text { desvio padrão }=0,8614 \\
& \text { desvio padrão: valor médio }=2,9265 \\
& \text { desvio padrão }=0,2401 \\
& \text { assimetria: } \quad \text { valor médio }=-0,0297 \\
& \text { desvio padrão }=0,4230 \\
& \text { curtose: } \quad \text { valor médio }=0,6973 \\
& \text { desvio padrão }=0,1798 \\
& \text { diâmetro médio: valor médio }=5,8552 \varnothing \\
& \text { desvio padrão }=0,7079 \\
& \text { desvio padrão: } \quad \text { valor médio }=2,8995 \\
& \text { desvio padrão }=0,1980 \\
& \text { assimetria: valor médio }=-0,2221 \\
& \text { desvio padrão }=0,3661 \\
& \text { curtose: valor médio }=0,6414 \\
& \text { desvio padrão }=0,0973
\end{aligned}
$$

Quanto ao diâmetro medio tem-se:

Formação Aquidauana - silte médio (variação de silte grosso a silte fino)

Grupo Tatuí - silte médio

Formação Piraçununga — não há dados calculados

Sedimentos quaternários - silte grosso (variação de areia muito fina a silte médio)

Regolito da Formação Aquidauana - silte médio (variação de silte grosso a silte fino) Regolito do Grupo Tatuí - silte médio (variação de silte grosso a silte fino)

Regolito de diabásio - silte médio (variação de silte médio a silte fino)

Conclui-se que:

I - o Grupo Tatuí apresenta granulação média igual à da Formação Aquidauana, mas esta última mostra variação, naturalmente retratando oscilações na sedimentação, em contraposição à uniformidade do Grupo Tatuí;

II - os sedimentos quaternários são mais grossos que os sedimentos paleozóicos, retratando deposição em condições mais energéticas; 
III - os regolitos de diabásio são mais finos do que os demais, pois se derivam de rochas providas de minerais intempericamente instáveis;
IV - os sedimentos quaternários são mais grossos do que os regolitos devido à atuação seletiva da deposição.

Quanto ao desvio padrão tem-se:

Formação Aquidauana - pobremente selecionado (variação de moderadamente a muito pobremente selecionado)

Grupo Tatuí - pobremente selecionado (variação de pobremente a muito pobremente selecionado)

Formação Piraçununga - não há dados calculados

Sedimentos quaternários - muito pobremente selecionados

Regolito da Formação Aquidauana - muito pobremente selecionado

Regolito do Grupo Tatuí - muito pobremente selecionado

Regolito de diabásio - muito pobremente selecionado

Conclui-se que:

I - a maior gama de variação da Formação Aquidauana sobre o Grupo Tatuí reflete maior variação na sedimentação;

II - os processos de seleção foram menos ativos para os sedimentos qua- ternários do que para os paleozóicos;

III - os processos intempéricos no $\mathrm{Su}-$ pergrupo Tubarão diminuíram a seleção (naturalmente devido à perda de silte).

Ouanto à assimetria tem-se:

Formação Aquidauana - assimetria positiva (variação de negativa a muito positiva)

Conclui-se que:

Formação Piraçununga - não há dados calculados

Sedimentos quaternários - assimetria muito positiva (variação de positiva a muito positiva)

Grupo Tatuí - assimetria positiva (variação de positiva a muito positiva)

Regolito da Formação Aquidauana - assimetria positiva (variação de negativa a muito positiva)

Regolito do Grupo Tatuí - aproximadamente simétrica (variação de muito negativa a muito positiva)

Regolito de diabásio - assimetria negativa (variação de muito negativa a positiva).

Conclui-se que:

I - o Grupo Tatuí possui maior distribuição nas classes mais finas que a Formação Aquidauana, a qual possui litologias mais grossas, denotando variação na sedimentação;

II - os sedimentos quaternários não se depositaram em ambiente mais calmo que o Supergrupo Tubarão (como se poderia supor), o que ocorre é que eles se derivaram em parte dos regolitos daquele supergrupo, menos providos de silte;

III — os dados dos regolitos não permitem interpretação geológica segura.

Quanto à curtose tem-se:

Formação Aquidauana - mesocúrtica (variação de platicúrtica a leptocúrtica)

Grupo Tatuí - mesocúrtica (variação de platicúrtica a leptocúrtica) 
Rev. IG, São Paulo, 3(2):23-52, jul./dez. 1982

Formação Piraçununga - não há dados calculados

Sedimentos quaternários - mesocúrtica (variação de platicúrtica a leptocúrtica)

Regolito da Formação Aquidauana - platicúrtica (variação de muito platicúrtica a mesocúrtica)

Regolito do Grupo Tatuí - platicúrtica (variação de muito platicúrtica a platicúrtica) Regolito de diabásio - muito platicúrtica (variação de muito platicúrtica a platicúrtica)

Conclui-se que:

I - quanto às médias da curtose não há distinção entre o Supergrupo Tubarão e os sedimentos quaternários;

II — os regolitos são predominantemente polimodais;
III - as formações geológicas de superfície autóctones têm as modas mais afastadas que as alóctones (quaternárias);

IV - os processos intempéricos levaram as unidades paleozóicas à polimodalidade.

7.1.3 Análise de frequiência do número de subclasses texturais

Formação Aquidauana

6

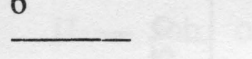

$\frac{7}{6,25 \%} \quad \frac{8}{12,50 \%}$

Grupo Tatuí

6

7

Formação Piraçununga

6

$\overline{5,41 \%}$

7

$8,11 \%$

8

$35,14 \%$

8

Sedimentos quaternários

$\overline{6,25 \%}$
8

$12,50 \%$
9

$\overline{25,00 \%}$
10

$37,50 \%$
11

$18,75 \%$
9

$66,67 \%$
10

$33,33 \%$
11

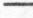

Regolito da Formação Aquidauana

9

$24,32 \%$
10

$21,62 \%$
11

$5,41 \%$
9

$31,25 \%$
10

$25,00 \%$
11

$18,75 \%$
6

$-$
7

$$
3,33 \%
$$

8

$20,00 \%$

Regolito do Grupo Tatuí

6

7

8

$40,00 \%$
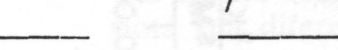

9

$36,67 \%$
10

$\overline{20,00 \%}$

11

$20,00 \%$

Regolito de diabásio

6

$7,14 \%$

7

$7,14 \%$

8

$14,29 \%$

9

$40,00 \%$
10

11

$20,00 \%$
9

$21,43 \%$
10

$28,57 \%$
11

$21,43 \%$ 


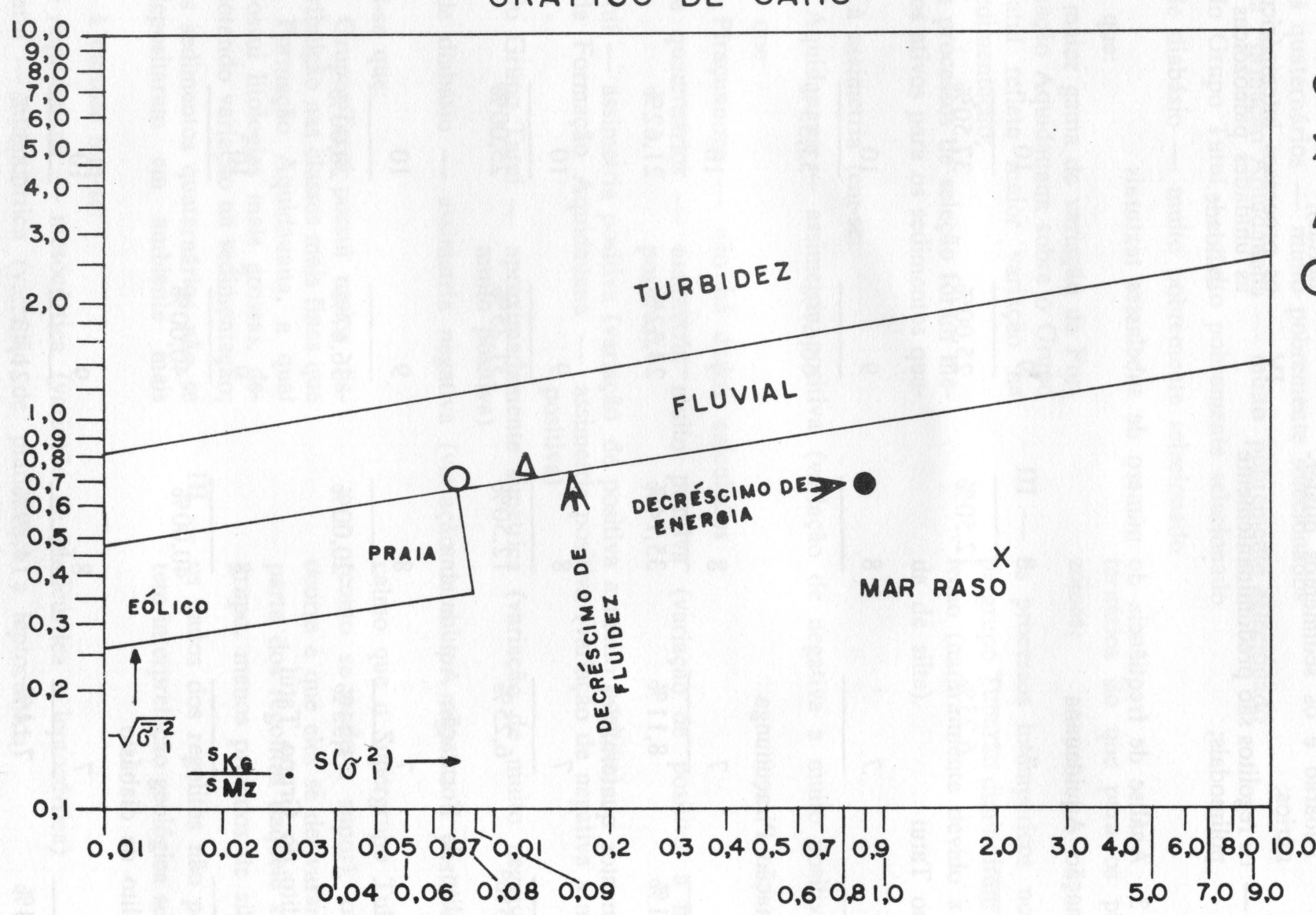

FIG. 4 
A Formação Aquidauana apresenta amostras com frequiência de subclasses texturais variando de 7 a 11 , com predominância de 10 e 9 subclasses; o Grupo Tatuí varia de 9 a 10 subclasses, com predominância de 9; a Formação Piraçununga varia de 6 a 11 subclasses, predominando 8 e 9 ; os sedimentos quaternários variam de 6 a 11 também, com predominância de 9 e 10 subclasses. Quanto aos regolitos, os da Formação Aquidauana variam de 7 a 11 subclasses, predominando 9, os do Grupo Tatuí variam de 8 a 11 (com exceção de 10), predominando 8 e 9; finalmente os regolitos de diabásio mostram variação de 6 a 11 subclasses, com predomínio de 10 .

Conclui-se que:

I - o Grupo Tatuí depositou-se em ambiente mais uniforme que a Formação Aquidauana (menor variação do número de subclasses texturais);

II - sob o aspecto proporcional, a Formação Aquidauana apresenta maior dispersão textural que o Grupo Tatuí;

III - os sedimentos quaternários apresentam maior dispersão de subclasses texturais que a Formação Piraçununga, o que é devido à maior presença de silte nos mesmos;

IV - o Supergrupo Tubarão possui maior dispersão de subclasses texturais que os sedimentos cenozói$\cos$, o que se justifica pela atuação de processos seletivos no material matriz originário desse supergrupo;

V - a Formação Aquidauana é ligeiramente portadora de maior dispersão que seu regolito, o que é devido à perda da classe silte no processo intempérico. O mesmo se diga do Grupo Tatuí;

VI - o regolito de diabásio mostra uma distribuição do número de subclasses texturais distinta dos regolitos das rochas sedimentares, o que denota sua diferente origem;

VII - os regolitos (formações geológicas de superfície autóctones) mostram ligeiramente maior dispersão textural que os sedimentos cenozóicos (formações geológicas de superfície alóctones), o que parece ser devido a um processo sedimentar seletivo degradando os regolitos e formando os depósitos modernos, especialmente com perda de argila.

\subsubsection{Gráfico de Sahu}

O Gráfico de Sahu, que apresenta as variações de energia e viscosidade e suas relações com os ambientes de sedimentação, (Figura 4) mostra que (Fração Areia):

I - os sedimentos quaternários formaram-se em condições um pouco mais energéticas que a Formação Piraçununga, a qual se formou também em condições mais energéticas que a Formação Aquidauana e esta mais que o Grupo Tatuí;

II - o Grupo Tatuí formou-se em condições mais fluidas que a Formação Aquidauana e essa em condições mais fluidas que a Formação Piraçununga e os sedimentos quaternários. A fluidez destes sedimentos é igual à da Formação Piraçununga;

III - o Supergrupo Tubarão está localizado na porção correspondente a mar raso. Quanto à Formação Aquidauana, o ambiente (ou ambientes) de sua geração não está totalmente definido pelos autores, parecendo predominar o flúvioglacial e não se descartando participação marinha. Quanto ao Grupo Tatuí, a baixa energia e alta fluidez estão condizentes com sua tranqüilidade litológica e o ambiente marinho é perfeitamente viável como interpretação;

IV - os sedimentos cenozóicos estão localizados no ambiente fluvial altamente energético, o que condiz com uma suposta deposição predominantemente em canais (especialmente para os sedimentos quaternários nos quais isso se verifica).

\subsection{Comparações granulométricas verticais}

Considera-se importante neste trabalho uma análise comparativa vertical, que será efetuada nos furos a trado onde foram tratadas granulometricamente amostras de diferentes profundidades. Os dados referemse à distribuição total. 


\section{Sondagem n.* 2 - Regolito do Grupo Tatuí}

2 a 6 metros diâmetro médio $0,0256 \mathrm{~mm}-5,2861 \varnothing$ (silte médio) desvio padrão 2,9469 (muito pobremente selecionado) assimetria 0,1474 (assimetria positiva) curtose 0,5905 (muito platicúrtica)

Shepard: areia argilosa

7 a 8 metros diâmetro médio $0,0271 \mathrm{~mm}-5,2066 \varnothing$ (silte médio) desvio padrão 3,0212 (muito pobremente selecionado) assimetria 0,0877 (aproximadamente simétrica) curtose 0,6132 (muito platicúrtica)

Shepard: areia argilosa

Os dados apresentados mostram haver pequeno aumento granulométrico de baixo para, cima, o que se traduz pelo diâmetro médio e pela assimetria.

\section{Sondagem n. ${ }^{0} 3$ - Formação Piraçununga}

0 a 2 metros diâmetro médio $0,0343 \mathrm{~mm}-4,8630 \varnothing$ (silte grosso) desvio padrão 3,0691 (muito pobremente selecionado) assimetria 0,2222 (assimetria positiva) curtose 0,5856 (muito platicúrtica) Shepard: areia argilosa

4 a 5 metros diâmetro médio $0,0323 \mathrm{~mm}-4,9507 \varnothing$ (silte grosso) desvio padrão 3,1313 (muito pobremente selecionado) assimetria 0,1084 (assimetria positiva) curtose 0,6258 (muito platicúrtica) Shepard: areia síltico argilosa

Os dados apresentados mostram haver ligeiro aumento granulométrico de baixo para cima, traduzido pelo diâmetro médio.

\section{Sondagem n.0 4 - Formação Piraçununga}

2 a 6 metros diâmetro médio $0,201 \mathrm{~mm}-5,6361 \varnothing$ (silte médio) desvio padrão 2,7356 (muito pobremente selecionado) assimetria 0,0027 (aproximadamente simétrica) curtose 0,5794 (muito platicúrtica)

Shepard: areia síltico argilosa

7,5 a 9 metros diâmetro médio $0,0165 \mathrm{~mm}-5,9176 \varnothing$ (silte médio) desvio padrão 2,5930 (muito pobremente selecionado) assimetria 0,1508 (assimetria negativa) curtose 0,6693 (muito platicúrtica)

Shepard: silte argilo arenoso

Os dados apresentados mostram haver aumento granulométrico de baixo para cima, traduzido pelo diâmetro médio, pela assimetria e pela classificação de Shepard.

\section{Sondagem n. ${ }^{0} 5$ - Formação Piraçununga}

0 a 4 metros diâmetro médio $0,0524 \mathrm{~mm}-4,2531 \varnothing$ (silte grosso) desvio padrão 3,3620 (muito pobremente selecionado) assimetria 0,3878 (assimetria muito positiva) curtose 0,5779 (muito platicúrtica)

Shepard: areia argilosa 
6 a 8 metros diâmetro médio $0,0599 \mathrm{~mm}-4,0615 \varnothing$ (silte grosso)

desvio padrão 3,5832 (muito pobremente selecionado)

assimetria 0,4069 (assimetria muito positiva)

curtose 0,5829 (muito platicúrtica)

Shepard: areia argilosa

Os dados apresentados mostram haver ligeiro aumento granulométrico de baixo para cima, o que fica traduzido pelo diâmetro médio.

\section{Sondagem n.0 7 - Formação Piraçununga \\ 0 a 2 metros diâmetro médio $0,0532 \mathrm{~mm}-4,2316 \varnothing$ (silte grosso) \\ desvio padrão 3,1393 (muito pobremente selecionado) \\ assimetria 0,5612 (assimetria muito positiva) \\ curtose 0,5785 (muito platicúrtica) \\ Shepard: areia argilosa \\ 2 a 4 metros diâmetro médio $0,0194 \mathrm{~mm}-5,6909 \varnothing$ (silte médio) \\ desvio padrão 2,9629 (muito pobremente selecionado) \\ assimetria 0,1979 (assimetria negativa) \\ curtose 0,6039 (muito platicúrtica) \\ Shepard: argila síltico arenosa}

Os dados apresentados mostram haver grande aumento granulométrico de baixo para cima, caracterizado pelo diâmetro médio, pela assimetria e pela classificação de Shepard.

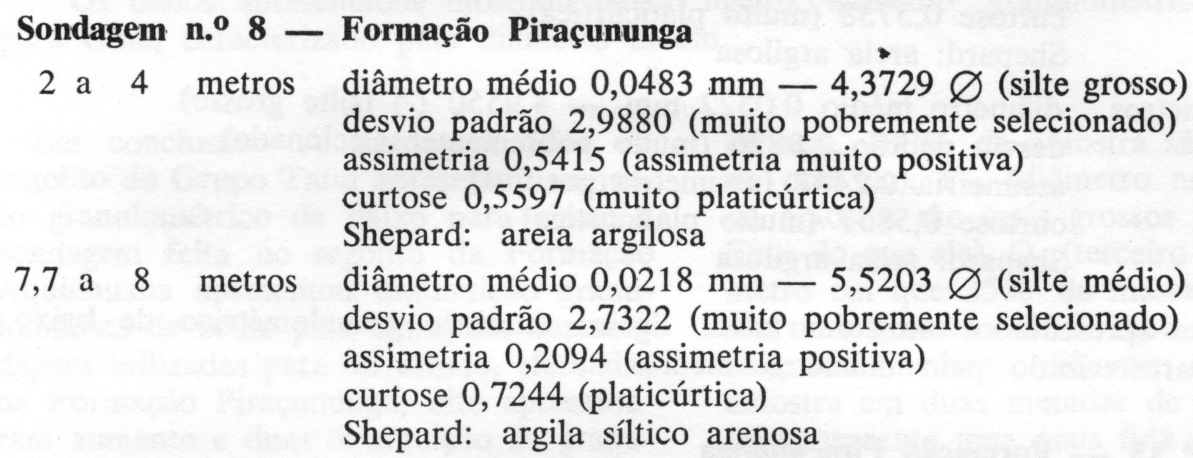

Os dados apresentados mostram haver aumento granulométrico de baixo para cima, caracterizado pelo diâmetro médio e pela classificação de Shepard.

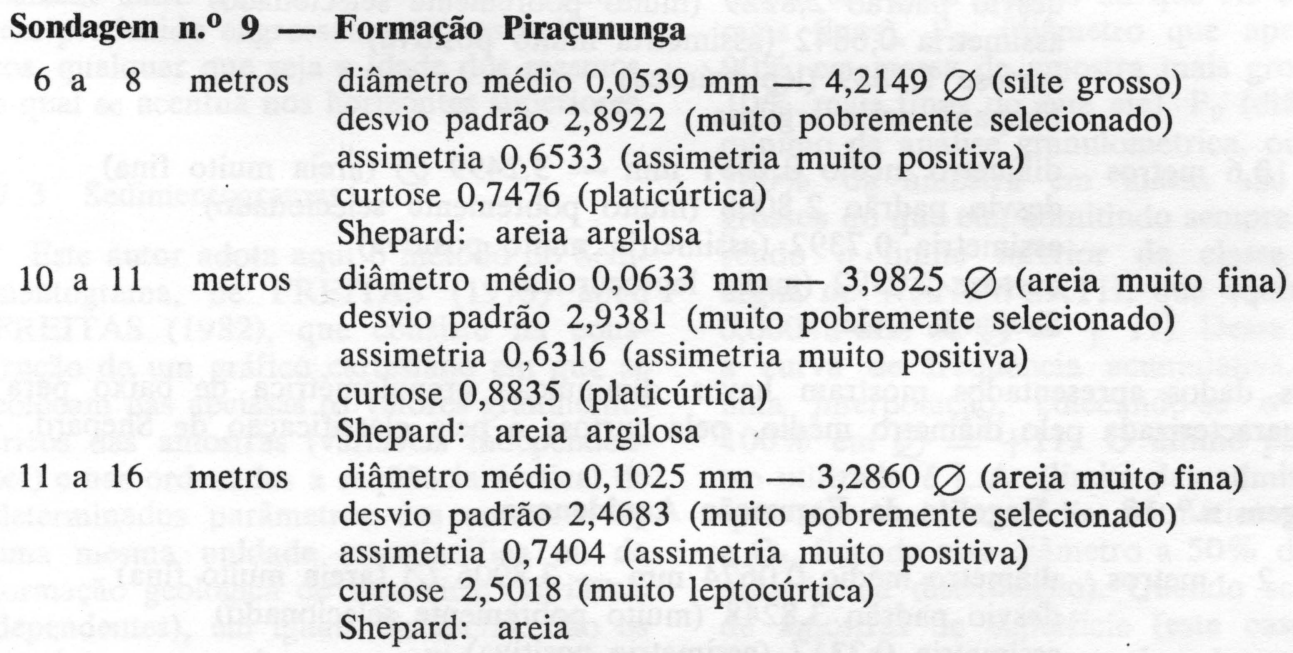

Os dados apresentados mostram haver diminuição granulométrica de baixo para cima, caracterizada pelo diâmetro médio e pela classificação de Shepard. 


\section{Sondagem n.` 11 - Formação Piraçununga \\ 0 a 4 metros diâmetro médio $0,0493 \mathrm{~mm}-4,3425 \varnothing$ (silte grosso) desvio padrão 2,8116 (muito pobremente selecionado) assimetria 0,6501 (assimetria muito positiva) curtose 0,7525 (platicúrtica) \\ Shepard: areia argilosa \\ 6 a 7 metros diâmetro médio $0,0233 \mathrm{~mm}-5,4251 \varnothing$ (silte médio) \\ desvio padrão 2,6664 (muito pobremente selecionado) assimetria 0,2599 (assimetria positiva) curtose 0,6442 (muito platicúrtica) \\ Shepard: argila síltico arenosa}

Os dados apresentados mostram haver ligeiro aumento granulométrico de baixo para cima, caracterizado pelo diâmetro médio, pela assimetria e pela classificação de Shepard.

\section{Sondagem n.0 14 - Formação Piraçununga}

2 a 4 metros diâmetro médio $0,0437 \mathrm{~mm}-4,5147 \varnothing$ (silte grosso) desvio padrão 2,9328 (muito pobremente selecionado) assimetria 0,5751 (assimetria muito positiva) curtose 0,5738 (muito platicúrtica) Shepard: areia argilosa

6 a 8 metros diâmetro médio $0,0322 \mathrm{~mm}-4,9550 \varnothing$ (silte grosso) desvio padrão 2,9826 (muito pobremente selecionado) assimetria 0,2447 (assimetria positiva) curtose 0,5857 (muito platicúrtica)

Shepard: areia argilosa

Os dados apresentados mostram haver ligeiro aumento granulométrico de baixo para cima, caracterizado pelo diâmetro médio.

\section{Sondagem n.` 15 - Formação Piraçununga}

2 a 6 metros diâmetro médio $0,0525 \mathrm{~mm}-4,2509 \varnothing$ (silte grosso) desvio padrão 2,8229 (muito pobremente selecionado) assimetria 0,6842 (assimetria muito positiva) curtose 1,1889 (leptocúrtica) Shepard: areia argilosa

10 a 10,6 metros diâmetro médio $0,1051 \mathrm{~mm}-3,2499 \varnothing$ (areia muito fina) desvio padrão 2,8008 (muito pobremente selecionado) assimetria 0,7392 (assimetria muito positiva) curtose 2,0992 (muito leptocúrtica) Shepard: areia

Os dados apresentados mostram haver diminuição granulométrica de baixo para cima, caracterizada pelo diâmetro médio, pela curtose e pela classificação de Shepard.

\section{Sondagem n. ${ }^{\circ} 18$ - Regolito da Formação Aquidauana}

0 a 2 metros diâmetro médio $0,0674 \mathrm{~mm}-3,8905 \varnothing$ (areia muito fina) desvio padrão 3,8248 (muito pobremente selecionado) assimetria 0,2317 (assimetria positiva) curtose: 0,5454 (muito platicúrtica) Shepard: areia argilosa 
Rev. IG, São Paulo, 3(2):23-52, jul./dez. 1982

2 a 4 metros diâmetro médio $0,1201 \mathrm{~mm}-3,0576 \varnothing$ (areia muito fina)

desvio padrão 3,5622 (muito pobremente selecionado)

assimetria 0,5566 (assimetria muito positiva)

curtose 1,0598 (mesocúrtica)

Shepard: areia argilosa

Os dados apresentados mostram haver ligeira diminuição granulométrica de baixo para cima, caracterizada pelo diâmetro médio.

\section{Sondagem n.0 19 - Formação Piraçununga}

2 a 4 metros diâmetro médio $0,0593 \mathrm{~mm}-4,0754 \varnothing$ (silte grosso)

desvio padrão 3,0396 (muito pobremente selecionado)

assimetria 0,6291 (assimetria muito positiva)

curtose 0,6214 (muito platicúrtica)

Shepard: areia argilosa

8 a 11 metros diâmetro médio $0,0564 \mathrm{~mm}-4,1473 \varnothing$ (silte grosso)

desvio padrão 2,9190 (muito pobremente selecionado)

assimetria 0,5530 (assimetria muito positiva)

curtose 0,8287 (platicúrtica)

Shepard: areia argilosa

Os dados apresentados mostram haver ligeiro aumento granulométrico de baixo para cima, caracterizado pelo diâmetro médio.

Em conclusão: A sondagem feita no regolito do Grupo Tatuí apresentou aumento granulométrico de baixo para cima; a sondagem feita no regolito da Formação Aquidauana apresentou diminuição granulométrica de baixo para cima; das dez sondagens utilizadas para tal estudo, efetuadas na Formação Piraçununga, oito apresentaram aumento e duas diminuição da granulometria de baixo para cima. Estes dados somados aos anteriormente apresentados deixam claro que o processo intempérico tem produzido engrossamento nos sedimentos, qualquer que seja a idade dos mesmos, o qual se acentua nos horizontes superiores.

\subsection{Sedimentogramas}

Este autor adota aqui o método do Sedimentograma, de FREITAS (1973) apud FREITAS (1982), que consiste na construção de um gráfico cartesiano em que se colocam nas abcissas os valores granulométricos das amostras (variáveis independentes) e nas ordenadas a seqüência vertical de determinados parâmetros das amostras de uma mesma unidade estratigráfica ou de formação geológica de superfície (variáveis dependentes), em iguais distâncias. São os seguintes os parâmetros utilizados, todos calculados a partir da análise granulométrica: $\mathbf{P}_{100}$ (diâmetro máximo da amostra, ou seja, $100 \%$ da amostra são mais finos do que ele), $\mathbf{P}_{90}$ (diâmetro no qual $10 \%$ da amostra são mais grossos e $90 \%$ mais finos do que ele), $\mathrm{Q}_{3}$ (terceiro quartel, diâmetro em que $25 \%$ da massa da amostra são mais grossos e $75 \%$ mais finos do que ele), Md (mediana, diâmetro que separa a amostra em duas metades de igual massa, evidentemente uma mais fina e outra mais grossa do que ele), $\mathrm{Q}_{1}$ (primeiro quartel, diâmetro em que $75 \%$ da amostra em massa são mais grossos do que ele e $25 \%$ mais finos), $\mathbf{P}_{10}$ (diâmetro que apresenta $90 \%$ em massa da amostra mais grossos e $10 \%$ mais finos do que ele), $P_{0}$ (diâmetro mínimo da análise granulométrica, ou seja, $100 \%$ da amostra em massa são mais grossos do que ele; admitindo sempre como sendo o limite inferior da classe ultra argila de WENTWORTH, que equivale a $0,00048 \mathrm{~mm}$ ou $\varnothing=+11$ ). Desse modo a curva de frequiência acumulativa sofre uma interpolação, colocando-se 0 valor $100 \%$ em $\varnothing=+11$. O último parâmetro utilizado é L.A. (limite das admisturas, que representa a média aritmética de $\mathbf{Q}_{1}$ e $\mathrm{Q}_{3}$, ficando esse diâmetro a $50 \%$ da granulação da distribuição). Quando se trata de amostras de superfície (este caso), as mesmas são lançadas no eixo das ordenadas segundo valores crescentes da L.A., de baixo para cima. 
A parte da amostra situada entre $\mathrm{P}_{100} \mathrm{e}$ $P_{90}$ é chamada de cauda grossa (representa $10 \%$ em massa da amostra), a situada entre $\mathrm{P}_{90}$ e $\mathrm{Q}_{3}$ recebe o nome de fração grossa (representa $15 \%$ ), a que fica entre $\mathrm{Q}_{3}$ e L.A. é denominada de admistura grossa, a situada entre L.A. e $Q_{1}$, admistura fina, a entre $Q_{1}$ e $P_{10}$, fração fina (representa $15 \%$ ) e a entre $\mathrm{P}_{10}$ e $\mathrm{P}_{0}$, cauda fina (representa $10 \%$ ). A soma das massas das admisturas representa $50 \%$ da amostra.

Os pontos das várias amostras correspondentes aos mesmos parâmetros são ligados entre si, configurando o espectro linear que caracteriza o sedimentograma. "O Sedimentograma consiste, pois, em um verdadeiro espectograma sedimentar à custa de medidas estatísticas (em $\mathrm{mm}$ ) e permite visualizar de uma maneira física e não matemática ou litológica empírica, a individualidade de uma Formação. Por este conceito uma Formação geológica apresenta sempre um mesmo espectograma linear no sedimentograma, admitindo-se uma discreta variação debitada a eventuais erros de análise granulométrica nos laboratórios de sedimentologia” FREITAS (1982) pág. 19.

Entendido que a mediana representa o ótimo da granulação da rocha sedimentar clástica no ambiente de sedimentação, o seu posicionamento na admistura grossa indica que o meio de sedimentação era de alta energia (agitado), enquanto que o seu posicionamento na admistura fina indica ambiente de deposição de baixa energia (baixa competência), inferior à do meio de transporte. Quando a competência do meio de transporte aproximava-se da competência do meio de deposição, o valor da mediana coincide com $o$ do limite das admisturas.

Isto posto, seguem-se as análises dos sedimentogramas. As coordenadas correspondem à posição de cada amostra na folha (UTM - Sistema Métrico), sendo X na direção E-W, Y na N-S da quadrícula e Z significando a altitude em metros.

\subsubsection{Formação Aquidauana (Figura 5)}

A expansão textural de $Q_{3}$ vai de areia fina a silte fino, enquanto que a de $Q_{1}$ vai de silte fino a argila média, o que impõe a L.A. uma expansão de areia muito fina a silte muito fino. A expansão textural da mediana, indo de areia fina a argila grossa mostra tratar-se de rochas com grande variação granulométrica.
As amostras de números 22 e 35-A caracterizam ambiente de deposição mais energético que o de transporte, o que poderia ter-se dado por retrabalhamento de sedimentos. As amostras 60, 27 e 24 caracterizam sítio de deposição de mesmo grau de energia que o de transporte, enquanto que as demais mostram que o ambiente de deposição foi menos energético que o de transporte. Essa interpretação está coerente com o ambiente glacial, flúvio-glacial, de correntes de turbidez e até marinho que se tem atribuído a essa formação.

\subsubsection{Grupo Tatuí (Figura 6)}

Conquanto estejam em análise apenas quatro amostras compondo o sedimentograma (o que não dá a visão tão completa desejável), algumas inferências importantes podem ser obtidas.

A expansão textural de $\mathrm{Q}_{3}$ vai de areia fina a silte grosso, enquanto que $\mathrm{Q}_{1}$ vai de silte grosso a silte fino, o que impõe a L.A. uma expansão textural de areia muito fina a silte médio. A mediana varia de silte grosso a silte médio, o que mostra que as rochas desse Grupo apresentam pequena variação granulométrica.

Duas amostras (87 e 16-A) caracterizam ambiente de deposição mais energético que o de transporte, enquanto que duas outras (14 e 15-A) caracterizam ambiente de deposição menos energético que o de transporte.

A pequena variação espectral de $\mathrm{Q}_{3}, \mathrm{Q}_{1}$ e Md caracteriza um ambiente de deposição homogêneo. Na falta de maior quantidade de amostras, nota-se que tanto um mar algo calmo quanto um ambiente fluvial pouco energético poderiam satisfazer aos dados apontados.

\subsubsection{Formação Piraçununga (Figura 7)}

A expansão textural de $Q_{3}$ vai de areia média a areia fina, enquanto que a de $\mathrm{Q}_{1}$ vai de areia fina a ultra argila, o que impõe a L.A. expansão de areia fina a areia muito fina. Isso mostra homogeneidade na metade grossa e heterogeneidade na metade fina. A expansão textural da mediana, indo de areia média a silte grosso mostra que se trata de sedimentos razoavelmente grossos, com pequena participação de finos. Aqui um novo aspecto deve ser ressaltado: a grande expansão espectral da admistura fina e da fração fina denotam que esses sedimentos são paupérrimos em silte. 
SEDIMENTOGRAMA DA FORMAÇÃO AQUIDAUANA

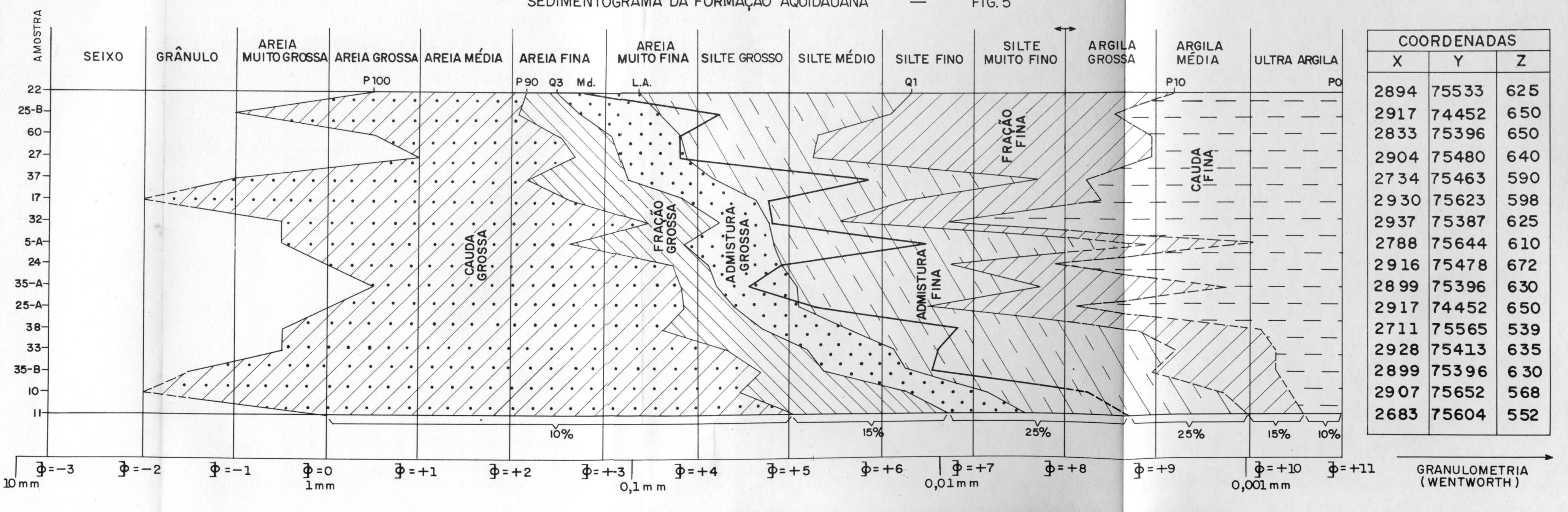


SEDIMENTOGRAMA DO GRUPO TATUÍ

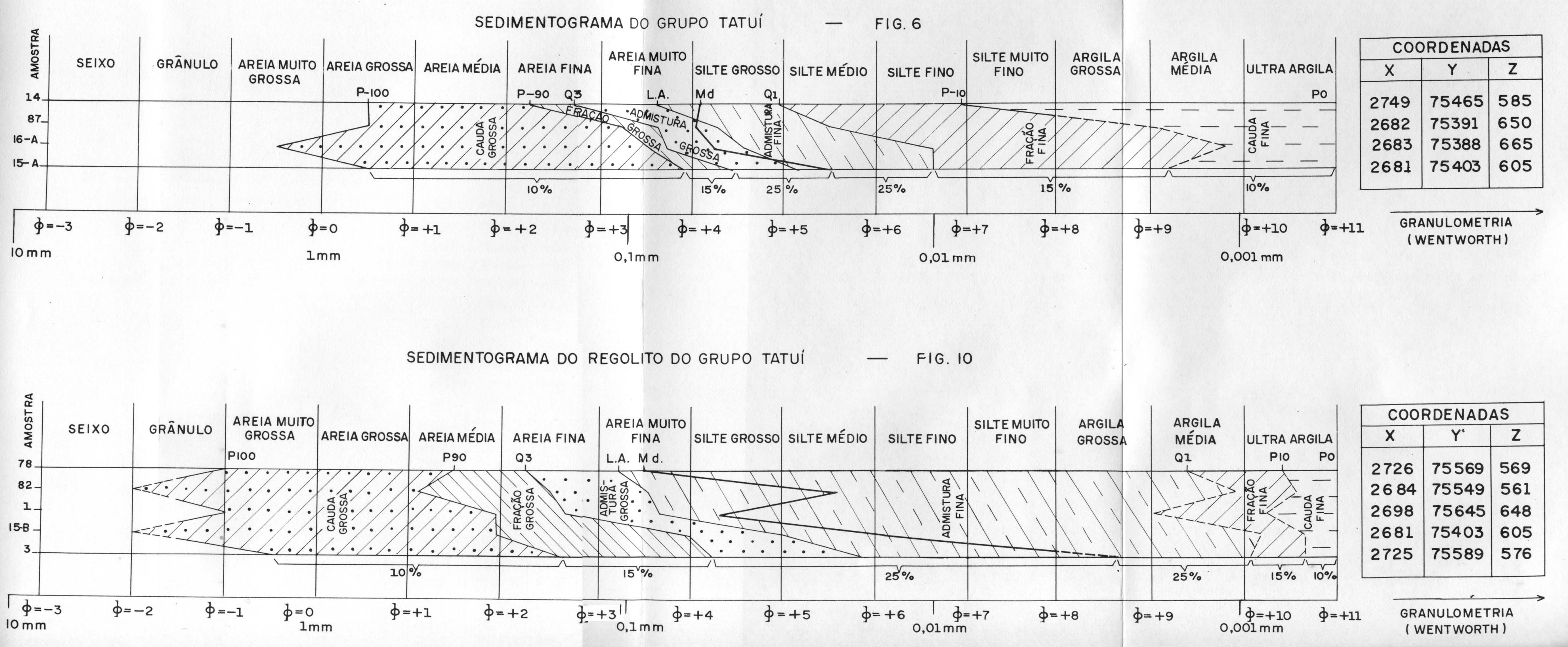




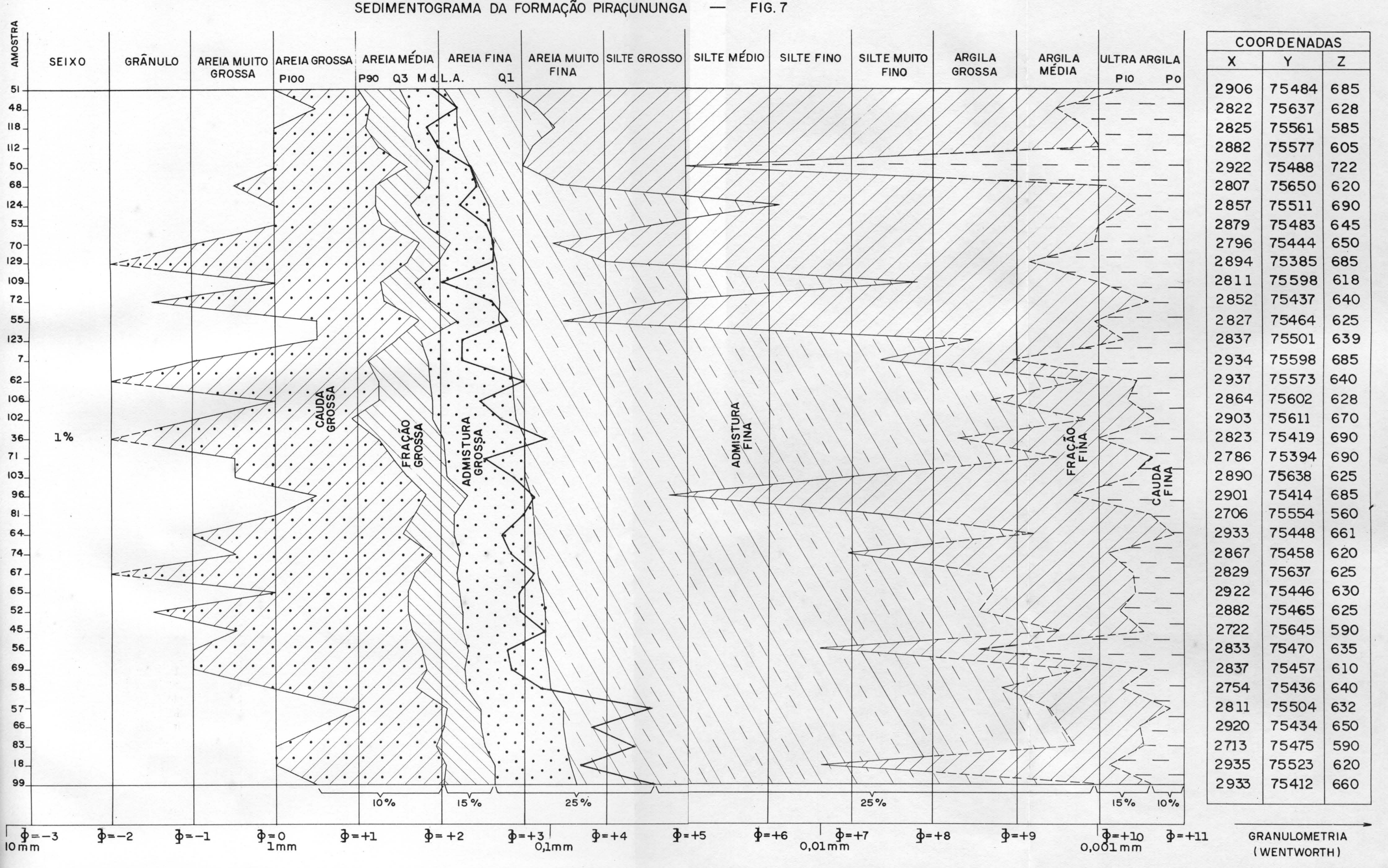




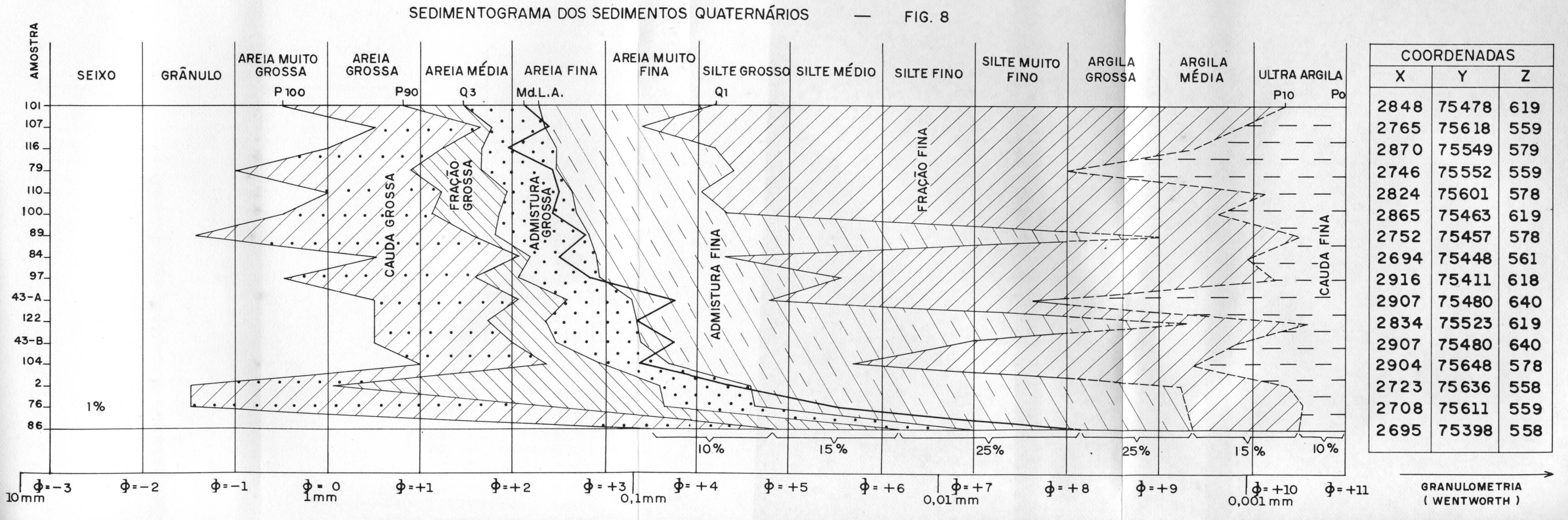




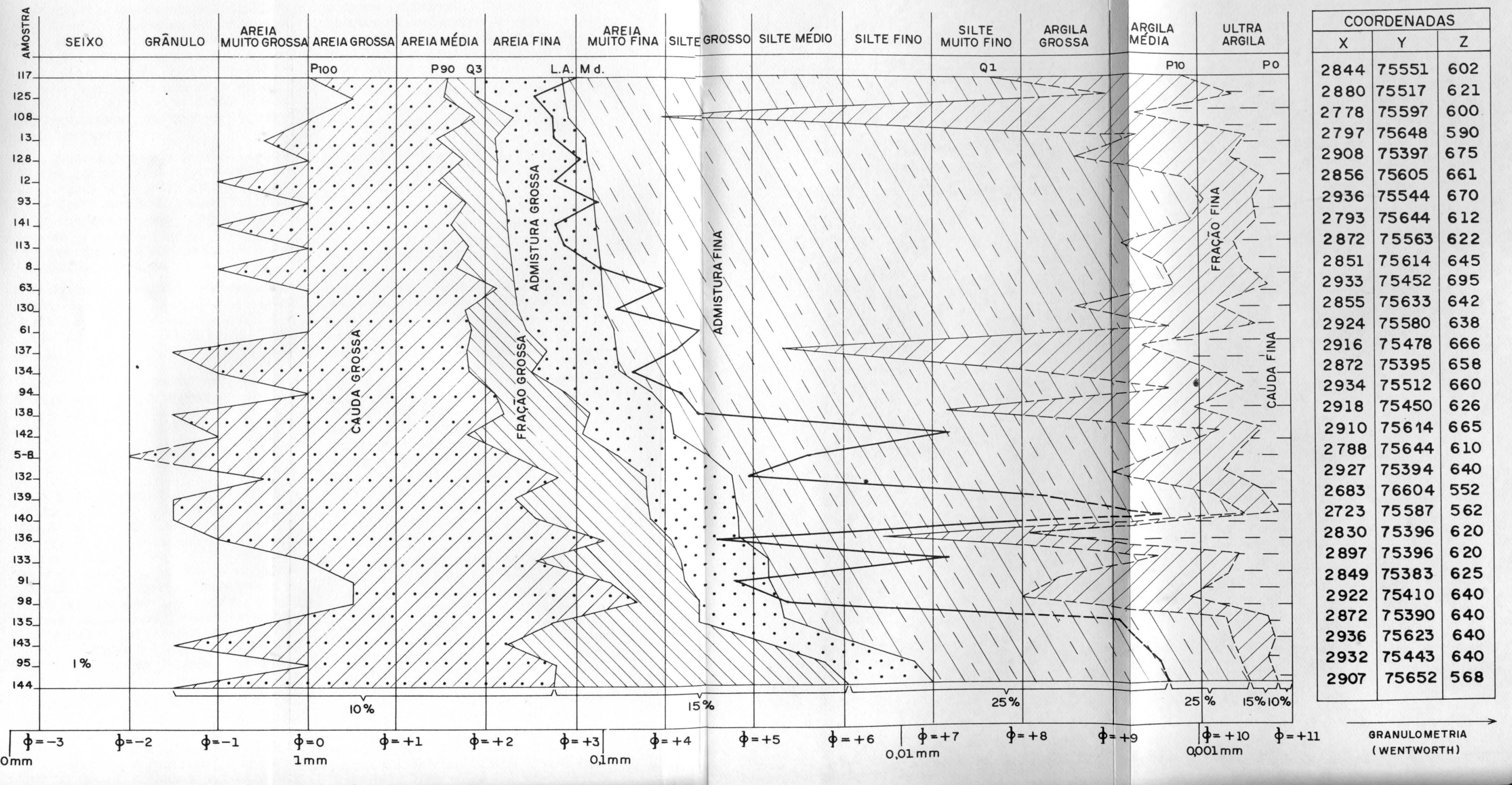


As amostras de números $55,62,36,57$, $66,83,18$ e 99 mostram Md do lado direito de L.A., o que lhes atribui meio de deposição menos energético que o de transporte; as amostras $48,50,68,70,129,96$ e 45 mostram que os dois meios tinham o mesmo nível energético; as demais (a maioria) caracterizam um meio de deposição altamente energético.

A pequena expansão textural de $\mathbf{Q}_{3}$ e Md em contraposição à grande de $\mathrm{Q}_{1}$; a permanência de $\mathrm{Q}_{3}$ e $\mathrm{Md}$ nas frações grossas e a alta energia do ambiente de deposição (comparável com a do transporte) indicam deposição fluvial em canais. Algumas das amostras apenas seriam de planícies de inundação.

A exígua quantidade de silte ao lado da grande quantidade de areia com alguma argila seria difícil de ser explicada meramente por processos deposicionais. Tudo indica que a fonte (ou fontes) desses sedimentos já seria desprovida de silte, entretanto também é possível que processos intempéricos tenham argilizado parte da fração síltica.

\subsubsection{Sedimentos quaternários} (Figura 8)

A expansão textural de $\mathrm{Q}_{3}$ vai de areia média a silte fino, enquanto que a de $\mathrm{Q}_{1}$ vai de areia muito fina a argila média, o que impõe a L.A. uma expansão de areia fina a silte muito fino. A mediana varia de areia fina a argila grossa. Essa grande variação dos parâmetros (especialmente da mediana) caracteriza pois grande variação textural das amostras. Nota-se entretanto que a maioria das mesmas é grossa e com grande expansão da admistura fina e fração fina, o que caracteriza areias com pouco silte.

Metade das amostras (101, 116, 110, $100,84,97,104$ e 2) apresenta a mediana à esquerda de L.A., o que caracteriza ambiente de deposição tão ou mais energético quanto o de transporte; as amostras, $107,79,89$ e 122 mostram os dois ambientes com o mesmo nível energético. As amostras, 43-A, 43-B, 76 e 86 são de ambiente de deposição menos energético que o de transporte; note-se que a amostra 86 está na planície de inundação do Rio Moji-Guaçu, a 76 na região de influência do Córrego das Palmeiras, enquanto que a $43-\mathrm{A}$ e a $43-\mathrm{B}$ pertencem a um terraço quaternário suspenso, pouco acima da boçoroca do este-sudeste da folha. Afora essas quatro amostras, as demais são de canal fluvial, o que está condizente com os dados obtidos.

A quase ausência de silte em metade das amostras é explicável pela ausência nos locais fonte, a maioria terciários.

\subsubsection{Formação Aquidauana versus \\ Regolito da Formação Aquidauana (Figuras, 5 e 9)}

$\mathrm{Na}$ comparação entre esses dois sedimentogramas nota-se um deslocamento dos parâmetros da parte grossa para a esquerda no regolito, inclusive a mediana e um deslocamento dos parâmetros da parte fina para a direita. No regolito há maior expansão textural da admistura fina e menor da cauda fina do que nas rochas da Formação; isso tudo significa que no processo intempérico a fração síltica e a argila mais grossa sofrem diminuição de diâmetro, passando a argila mais fina e especialmente ultra argila. Em virtude de ainda não ter sido feito estudo a respeito, é suposto neste trabalho que parte dessas frações mais finas do sedimento original sofram aglutinação, dando o mostrado aumento da fração grossa no manto de intemperismo.

\subsubsection{Grupo Tatuí versus Regolito do Grupo Tatuí (Figuras, 6 e 10)}

$\mathrm{Na}$ comparação entre esses dois sedimentogramas nota-se um deslocamento de L.A., $\mathrm{Md}, \mathrm{Q}_{1}$ e $\mathrm{P}_{10}$ (parâmetros mais finos) para a direita e um deslocamento de $\mathrm{P}_{100}$ e $\mathrm{P}_{90}$ para a esquerda das rochas do Grupo para o regolito. $\mathrm{Q}_{3}$ permanece com a mesma expansão granulométrica. Nota-se também grande aumento espectral da admistura fina e diminuição da fração fina e da cauda fina. Isso tudo significa que no processo intempérico ocorreu diminuição da fração síltica e aumento da argila média e ultra argila; houve também diminuição das subclasses, areia fina e areia muito fina. Aqui aplica-se o mesmo raciocínio quanto à transformação da classe síltica aplicado à Formação Aquidauana.

\subsubsection{Regolito de diabásio (Figura 11)}

A expansão textural da mediana vai de silte grosso a argila média, o que dá às amostras um caráter de material fino, 
mesmo por que $\mathrm{Q}_{3}$ não alcança subclasses mais grossas que areia fina. Nesse conjunto de amostras há que se considerar que muitas delas são de material com alguma mistura, o que promoveria um natural engrossamento. Assim as amostras, $73,54,105,121,120,119,90,75$ e 80 foram coletadas em solos sem afloramento ou distantes de afloramentos e nota-se que as de números $73,54,105,121$ e 120 ficam com a mediana na subclasse silte grosso, enquanto que as demais amostras ficam com a mediana entre silte muito fino e argila média. Naturalmente essas cinco últimas amostras são de material com contribuição mais grossa.

Especial atenção merece a amostra 88 , que embora coletada acima de afloramento mostra uma mediana grossa (silte grosso), além de só ela apresentar mediana à esquerda de L.A. e presença de seixos. E a única coletada na margem esquerda do Rio Moji-Guaçu e, pois, representa uma outra geração de diabásio, já que esse rio constitui-se em alinhamento estrutural contendo um falhamento com bloco elevado do lado direito.

\subsubsection{Formação Aquidauana versus Grupo Tatuí (Figuras, 5 e 6)}

A grande variação textural de $\mathrm{Q}_{3}, \mathrm{Md}$ e $\mathrm{Q}_{1}$ na Formação Aquidauana, em contraposição a uma variação pequena no Grupo Tatuí deixa claro que na primeira estão envolvidos vários ambientes ou subambientes, enquanto que no segundo já há mais uniformidade ambiental.

\subsubsection{Formação Piraçununga versus sedimentos quaternários (Figuras, 7 e 8)}

$\mathrm{Na}$ comparação entre esses dois sedimentogramas nota-se que, sem exceção, codos os parâmetros da Formação Piraçununga alcançam frações mais grossas que os dos sedimentos quaternários. Esse caráter mais grosso da referida formação fica muito bem evidenciado pela posição de sua mediana que se situa bem à esquerda, se relacionada à posição da mediana daqueles sedimentos.

Outro aspecto ressaltado pelos sedimentogramas é que há muito mais uniformidade granulométrica na Formação Piraçununga que nos sedimentos quaternários, especialmente nas frações mais grossas. Os espectros, da admistura grossa e da fração grossa são menos espalhados na citada Formação.

Isso tudo sugere que o ambiente de constituição da Formação Piraçununga era mais energético que $\mathrm{o}$ dos sedimentos quaternários. Entretanto existe a hipótese de que os dados reflitam que parte dos sedimentos quaternários tenha como fonte de suprimento, não só a Formação Piraçununga, como também o Supergrupo Tubarão e os diabásios, que são mais finos. É possível ainda que isso reflita o retrabalhamento dos sedimentos anteriores, com diminuição dos tamanhos dos detritos.

\subsubsection{Formação Aquidauana mais Grupo Tatuí versus Formação Piraçununga mais sedimentos quaternários (Figuras, 5, 6, 7 e 8)}

Uma interessante comparação pode ser feita entre os sedimentos permocarboníferos e os cenozóicos. No todo, os sedimentogramas da Formação Piraçununga e dos sedimentos quaternários mostram um deslocamento para o lado grosso, tanto de $\mathrm{Q}_{3}$ quanto de $\mathrm{Md}$ com relação aos sedimentogramas, da Formação Aquidauana e do Grupo Tatuí. Os espectros, da admistura fina e da fração fina são mais espalhados no conjunto cenozóico. Esses fatos reunidos mostram que os sedimentos paleozóicos são mais finos, correspondendo a ambientes menos energéticos.

\section{ESTRUTURAS}

A área da folha caracteriza-se como um grande monoclinal, com as camadas inclinando-se suavemente em direção à calha do Rio Moji-Guaçu.

Existem duas direções gerais de alinhamentos estruturais evidenciadas pelas orientações dos principais rios, Moji-Guaçu, Jaguari-Mirim, da Itupeva e Capetinga, que são: NNW-SSE e E-W. Elas ficam bem mostradas pela inflexão de noventa graus à direita que o Rio Capetinga faz no sudoeste da folha. Essa mesma inflexão é feita pelo Rio Moji-Guaçu ao sul da área objeto deste trabalho. O Rio da Itupeva apresenta o mesmo aspecto com alternados trechos seguindo esses direcionamentos. 
SEDIMENTOGRAMA DO REGOLITO DE DIABÁSIO

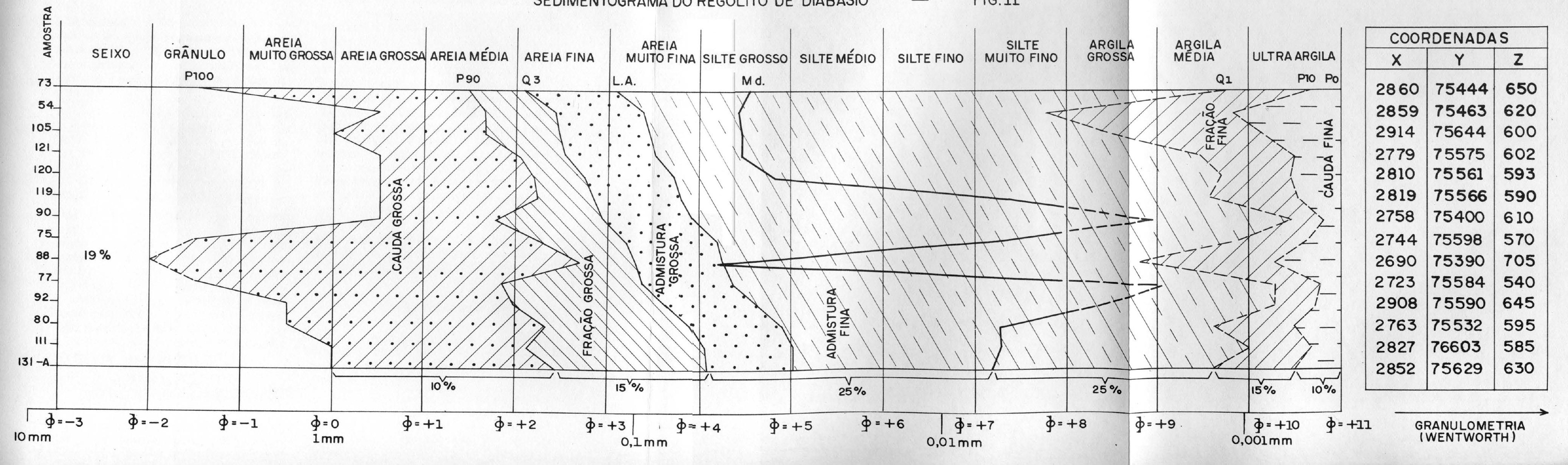


Regionalmente essas direções ficam bem nítidas quando observadas em imagens do Satélite Landsat, constituindo-se nos alinhamentos desta porção do país, mostradas pelos rios: Pardo, Moji-Guaçu, do Peixe, Sapucaí-Mirim, Jaguari-Mirim e alto Rio Grande. SINELLI (1971) concorda com esta observação. COIMBRA et alii (1981) ligam a intrusão alcalina de Jaboticabal, a intrusão alcalina de Araçoiaba da Serra e as falhas do sistema Ipeúna-Piracicaba ao alinhamento do Moji-Guaçu. O alto trecho desse rio acompanha o falhamento Jacutinga-Ouro Fino.

Segundo GANDOLFI (1971), a drenagem manifesta a constituição geológica, desde que o Rio Moji-Guaçu atravessa indiferentemente a área sedimentar, desviando-se ao atingir as estruturas dos magmatitos básicos. SOARES (1973) fala de padrões estruturais bem diversificados no Neopaleozóico e Mesozóico do Estado de São Paulo.

As direções de lineamentos estruturais são mais variadas, aparecendo a vários ângulos a NW e NE. Nas regiões das folhas de Santa Rita do Passa Quatro, Corumbataí, Leme, Piraçununga e Descalvado, elas estão em parte preenchidas por diabásio, caracterizando falhamentos.

Esse arcabouço estrutural tem dado à drenagem um padrão retangular aos rios principais e dendrítico aos menores. Em imagens Landsat fica evidente que quanto à densidade de textura de relevo, a zona de ocorrência da Formação Aquidauana, bem como sedimentos modernos (à qual pertence esta folha), é bem mais lisa que a parte leste (pré-cambriana) e oeste, esta com sedimentos meso-cenozóicos, diabásios e escarpas da Serra Geral.

\section{DADOS PALEOGEOGRÁFICOS}

Não se dispõe no presente trabalho de elementos suficientes para configurar a paleogeografia da área da folha, entretanto sondagens geofísicas pelo método da eletrorresistividade no Distrito de Lagoa Branca, pouco ao norte, na Folha de Casa Branca (SOUZA et alii, 1982), mostraram que o embasamento cristalino está a profundidade maior que 400 metros. Considerando que as rochas pré-cambrianas já afloram na folha contígua leste de Aguaí (a partir de 10 quilômetros do extremo leste desta área); considerando também que existe um aumento regional de freqüência de diamictitos na Formação Aquidauana para leste; considerando ainda que o Grupo Tatuí só ocorre na parte oeste, esses fatos todos sugerem como fonte de suprimento de detritos a área pré-cambriana de leste.

Um fato muito importante merece ser destacado; estratigraficamente acima dos depósitos Aquidauana e Tatuí (respectivamente Permocarbonífero e Permiano médio) só ocorrem sedimentos inconsolidados supostamente terciários e/ou aluviões quaternários em calhas de rios ou baixios. Por que tão grande vazio estratigráfico? Evidentemente duas hipóteses acadêmicas são possíveis: houve sedimentação intermediária e erosão posterior, ou não houve sedimentação, permanecendo a região sempre topograficamente alta. Os corpos de diabásio, agora aflorantes, denotam ter havido ampla atividade erosiva após o Juro-Cretáceo, a qual estaria pois encerrada ainda no Cretáceo final, com posterior início de afundimento tectônico da Depressão Periférica Paulista e constituição das escarpas da Serra Geral. A partir daí deu-se o entulhamento da região pelo aporte de sedimentos vindos predominantemente de leste. A drenagem exorreica tal qual é hoje conhecida só posteriormente ter-se-ia estabelecido, ao que tudo indica, por linhas tectônicas reativadas e quiçá por deslocamentos de blocos, através de fases de entalhe e aplainamento sucessivas.

\section{CONSIDERAÇÕES FINAIS}

$1 .^{\mathrm{a}}$ - A área estudada situa-se geomorfologicamente no Setor Aguaiano da Zona do Moji-Guaçu, da Depressão Periférica do Estado.

$2 .^{\text {a }}$ - A Formação Piraçununga (provavelmente terciária) ocupa $65 \%$ da folha, capeando as unidades geológicas mais antigas (Formação Aquidauana, Grupo Tatuí) e diabásios como uma película que normalmente não ultrapassa os onze metros de espessura.

$3 .^{\text {a }}$ - As formações geológicas de superfície alóctones são cenozóicas (Formação Piraçununga e sedimentos quaternários), espalhando-se por todas as posições topográficas, como espigões, meias encostas, vales e baixios. As formações geológicas de superfície autóctones compõem-se de regoli- 
tos do Supergrupo Tubarão (Formação Aquidauana e Grupo Tatuí) e de diabásios, formando corpos isolados também em todas as posições topográficas.

4. a - Alguns mantos de intemperismo de diabásio apresentam elevada quantidade de grãos de quartzo, que só pode ser explicada pela contribuição das formações sedimentares arenosas locais.

5. a - A Formação Piraçununga é mais espessa nos espigões, que caracterizam a superfície de aplainamento mais antiga (provavelmente terciária), o que indica que sua sedimentação deu-se nesse período.

6. ${ }^{a}$ - Os processos de intemperismo levaram os materiais preexistentes a uma perda de silte, reconhecível na comparação granulométrica entre as rochas do Supergrupo Tubarão e seus regolitos, bem como nas análises feitas em diferentes profundidades nas sondagens efetuadas.

7. a - O método do Sedimentograma (FREITAS, 1973) apud FREITAS (1982), mostrou-se perfeitamente aplicável às rochas, sedimentos e regolitos da área.

8. a - Os dados sedimentológicos sugerem ambiente de mar raso para o Grupo Tatuí, não descartam ambiente flúvio-glacial para a Formação Aquidauana, sugerem am- biente fluvial para a Formação Piraçununga e confirmam o ambiente energético fluvial constatado para os sedimentos quaternários.

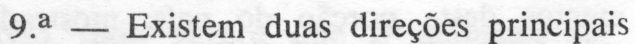
de alinhamentos estruturais, NNW-SSE e E-W, evidenciadas pelos rios: Moji-Guaçu, Jaguari-Mirim, da Itupeva e Capetinga.

$10 .^{a}$ - A área da folha não é propícia à exploração econômica de bens minerais. Apenas alguns diabásios têm sido aproveitados como pedra britada.

\section{AGRADECIMENTOS}

O autor expressa seus mais sinceros agradecimentos ao Dr. Ruy Osório de Freitas, Coordenador do presente projeto e ao Dr. Sérgio Mezzalira, orientador, pelos seguros ensinamentos; aos geólogos, Jorge Hachiro, Lauro Kazumi Dehira e Lídia Keiko Tominaga pela colaboração nos trabalhos de sondagens, às geólogas, Márcia Maria Ncgueira Pressinotti e Anna Artemísia Barracco de Azevedo pelos trabalhos sedimentológicos, bem como aos técnicos de laboratório Elizabete Kosue Higaki Pedroso e Estevão Giaccone e aos desenhistas do Instituto Geológico, chefiados pelo Sr. Flávio Basile, pelos trabalhos de sua alçada, caracterizados pela dedicação.

\section{REFERÊNCIAS BIBLIOGRĀFICAS}

ABREU, A.A. - 1973 - Tentativa de compartimentação e estruturação das paisagens do médio vale do Jaguari-Mirim. São Paulo, Universidade, Instituto de Geografia. $24 \mathrm{p}$. (Geomorfologia, 39)

ALMEIDA, F.F.M. de \& BARBOSA, O. - 1953 - Geologia das quadrículas de Piracicaba e Rio Claro, Estado de São Paulo. Rio de Janeiro, DNPM, Divisão de Geologia e Mineralogia. 96p. (Boletim, 143)

- -1954 - Geologia do centro-leste Mato-grossense. Rio de Janeiro, DNPM, Divisão de Geologia e Mineralogia. 97p. (Boletim, 150)

- 1974 - Fundamentos geológicos do relevo paulista. São Paulo, Universidade, Instituto de Geografia. 110p. (Série Teses e monografias, 14)

BRASIL. DEPARTAMENTO NACIONAL DA PRODUÇÃO MINERAL - 1977 - Projeto Sapucaí; relatório final-geologia. São Paulo, CPRM/DNPM. 4v. - 1979a - Geologia das regiõe de Mato Grosso do Sul; Projeto Bodoquena. Brasília. 11p. (Série Geologia, 6. Seção Geologia Básica, 3)
dos de Minas Gerais e São Paulo|; relatório final de geologia. Brasília, DNPM/CPRM, Superintendência Regional de São Paulo. 299p. il. 4 mapas col. (Série: Geologia, 5. Seção Geologia Básica, 2)

COIMBRA, A.M. et alii - 1981 - Silicificação dos arenitos da Formação Bauru no Estado de São Paulo. In: SOCIEDADE BRASILEIRA DE GEOLOGIA. NÚCLEO DE SÃO PAULO. Mesa Redonda: A Formação Bauru no Estado de São Paulo e regiões adjacentes; coletânea de trabalhos e debates; São Paulo, 10-12 de novembro de 1980. São Paulo. p 103-111. (Publicação especial SBG-SP, n. ${ }^{\circ}$ 7)

COTTAS, L.R. et alii - 1981 - Divisão faciológica do Subgrupo Itararé e da Formação Aquidauana no nordeste do Estado de São Paulo. In: SIMPÓSIO REGIONAL DE GEOLOGIA, 3.․, Curitiba. Atas. São Paulo, Sociedade Brasileira de Geologia, Núcleo de São Paulo. v.2 p.103-115.

FIORI, A.P. \& LANDIM, P.M.B. - 1980 Estratigrafia do Grupo Tubarão (Formação Aquidauana) na região sudoeste do Estado de Minas Gerais. Anais da Academia Brasileira de Ciências, Rio de Janeiro, 52(1):109124, mar. 
FREITAS, R.O. de - 1953 - Ensaio sobre o relevo tectônico do Brasil. Revista Brasileira de Geografia, Rio de Janeiro, 13(2):171-222.

et alii - 1979 - Projeto de levantamento geológico de formações superficiais. In: SIMPÓSIO REGIONAL DE GEOLOGIA, 2. ${ }^{\circ}$, Rio Claro. Atas. São Paulo, Sociedade Brasileira de Geologia. v.2 p.263277.

- 1982 - Definição estratigráfica do Grupo Bauru por sedimentogramas. São Paulo, Instituto Geológico. 86p. (Boletim, 6)

FÚLARO, V.J. - 1971 - A evolução tectônica e paleogeográfica da bacia sedimentar do Paraná pelo "Trend surface analysis". São Carlos, Escola de Engenharia de São Carlos, USP. 112p. (Geologia, 14)

- 1979 - O Cenozóico na bacia do Paraná. In: SIMPÓSIO REGIONAL DE GEOlOGIA, 2., Rio Claro. Atas. São Paulo, Sociedade Brasileira de Geologia. v. 1 p.231-241.

FURLANI, G.M. - 1969 - As boçorocas de Casa Branca e seu significado geomorfológico. São Paulo, Universidade, Instituto de Geografia. p.12-15. (Geomorfologia, 10)

GANDOLFI, N. - 1971 - Investigações sedimentológicas, morfométricas e físico-químicas nas bacias do Moji-Guaçu, do Ribeira de Iguape e do Peixe. São Carlos, Escola de Engenharia de São Carlos, USP. 108p. (Geologia, 15)

GONÇALVES, N.M.M. - 1978 - Estudo dos materiais superficiais da região de Ribeirão Preto, SP e suas relações com elementos morfológicos da paisagem. São Paulo. Tese de Mestrado, Instituto de Geociências USP. $177 \mathrm{p}$.

MODENESI, M.C. - 1974a - Contribuição à geomorfologia da região de Itu-Salto: estudo de formações superficiais. São Paulo, Universidade, Instituto de Geografia. 99p. (Série Teses e monografias, 10)

- - 1974b - Níveis de erosão e formações superficiais na região de Itu-Salto, SP. Revista Brasileira de Geociências, São Paulo, 4(4):228-246.

PENTEADO, M.M. - 1976 - Geomorfologia do setor centro-ocidental da depressão periférica paulista. São Paulo, Universidade, Instituto de Geografia. 86p. (Série Teses e monografias, 22)

PONÇANO, W.L. et alii - 1980 - Carta geomorfológica do Estado de São Paulo, na escala 1:250.000, com base no conceito de sistemas de relevo. In: CONGRESSO BRASILEIRO DE GEOLOGIA, 31. ${ }^{\circ}$, Balneário de Camboriú, SC. Anais. Balneário de Camboriú, SC., Sociedade Brasileira de Geologia. v. 2 p. 1013-1025.

PETROBRÁS, Rio de Janeiro - 1971 - Mapa geológico, semidetalhe do centro-leste de São Paulo; bacia do Paraná [por] Sebastião Maia de Andrade [e] Paulo César Soares. [Rio de Janeiro] PETROBRÁS DESUL. Escala 1:100.000. (Relatório 407 Anexo 20 Folha SF-23-M-II)
SÃO PAULO. DEPARTAMENTO DE ÁGUAS E ENERGIA ELÉTRICA - 1975 - Estudo de águas subterrâneas; região administrativa 6, Ribeirão Preto. São Paulo. v.3 mapas.

SÃO PAULO. DEPARTAMENTO DE ÁGUAS E ENERGIA ELÉTRICA/UNIVERSIDADE ESTADUAL JULIO DE MESQUITA FILHO - 1981 - Folha de Campinas. São Paulo. Escala 1:250.000. Inédito.

SÃO PAULO. INSTITUTO GEOGRÁFICO E GEOLÓGICO - 1965 - Folha geológica provisória de Araras [por] Sérgio Mezzalira. São Paulo. Escala 1:100.000. (SF-23-M-200) Inédito.

SÃO PAULO. INSTITUTO GEOLÓGICO 1980 - Formações superficiais; folha geológica de Leme [por] Carlos de Carvalho Torres; Geraldo Hideo Oda [e] Percy Corrêa Vieira. São Paulo. Escala 1:50.000 (SF-23-Y-A-II-1)

- -1981 - Formações geológicas de superfície; folha geológica de Santa Rita do Passa Quatro [por] Marcos Massoli. São Paulo. Escala 1:50.000. (SF-23-V-C-V-1)

- 1981 - Formações geológicas de superfície; folha geológica de Rio Capetinga [por] Percy Corrêa Vieira. São Paulo. Escala 1:50.000. (SF-23-Y-A-II-2)

- -1981 - Formações geológicas de superfície; folha geológica de Piraçununga [por] Lauro Kazumi Dehira. São Paulo. Escala 1:50.000. (SF-23-V-C-V-3)

- 1982 - Formações geológicas de superfície; folha geológica de São João da Boa Vista [por] Lídia Keiko Tominaga. São Paulo. Escala 1:50.000. (SF-23-V-C-VI-3)

- 1982 - Formações geológicas de superfície; folha geológica de Aguaí [por] Geraldo Hideo Oda; Marcos Massoli [e] Carlos de Carvalho Torres. São Paulo. Escala 1:50.000. (SF-23-Y-A-III-1) Em preparação para publicação.

- -1982 - Formações geológicas de superfície; folha geológica de Casa Branca [por] Jorge Hachiro; Geraldo Hideo Oda; Marcos Massoli [e] Carlos de Carvalho Torres. São Paulo. Escala 1:50.000. (SF-23-VC-V-4). Em preparação para publicação.

- 1982 - Formações geológicas de superfície; folha geológica de Corumbataí [por] Carlos de Carvalho Torres; Marcos Massoli [e] Lídia Keiko Tominaga. São Paulo. Escala 1:50.000. (SF-23-Y-A-I-2) Em preparação para publicação.

- 1982 - Formações geológicas de superfície; folha geológica de Descalvado [por] Marcos Massoli; Carlos de Carvalho Torres [e] Percy Corrêa Vieira. São Paulo. Escala 1:50.000. (SF-23-V-C-IV-4) Em levantamento de campo.

SINELLI, O. - 1971 - Considerações gerais sobre a tectônica do Município de Ribeirão Preto. In: CONGRESSO BRASILEIRO DE GEOLOGIA, 25..$^{\circ}$ São Paulo. Anais. São Paulo, Sociedade Brasileira de Geologia. v.2 p. 145-152. 
SOARES, P.C. - 1972 - O limite glacial-pósglacial do Grupo Tubarão em São Paulo. Anais da Academia Brasileira de Ciências, Rio de Janeiro, Supl. 44:333-341.

$$
\text { - } 1973 \text { - Tipos dominantes de }
$$
estruturas apresentadas pela tectônica da bacia do Paraná em São Paulo. Ciência e Cultura, São Paulo, Supl. 25(6):182.

$$
\text { \& LANDIM, P.M.B. - } 1973 \text { - }
$$

Aspectos regionais da estratigrafia da bacia do Paraná no seu flanco nordeste. In: CONGRESSO BRASILEIRO DE GEOLOGIA, 27. ${ }^{\circ}$ Aracaju. Anais. Aracaju, Sociedade Brasileira de Geologia. v. 1 p.243-256. \& - 1976 - Depósitos cenozóicos na região centro-sul do Brasil. Notícia Geomorfológica, Campinas, 16(31): 17-39.
SOARES, P.C. et alii - 1978 - Tectonic cycles and sedimentary sequences in the Brazilian intracratonic basins. Geological Society of America Bulletin. Boulder, Colo., 89(2):181191.

SOUZA, A. et alii - 1982 - Geologia e hidrogeologia da região do Distrito de Lagoa Branca, Casa Branca, SP; aplicação de sondagem elétrica. Revista do Instituto Geológico, São Paulo, 3(1):15-23.

WASHBURNE, C.W. $-1930-$ Petroleum geology of the States of São Paulo, Brazil. São Paulo, Comissão Geographica e Geologica. 282p. (Boletim, 22)

WOHLERS, A. - 1964 - Cenozóico. In: SÃO PAULO. INSTITUTO GEOGRÁFICO E GEOLÓGICO. Geologia do Estado de São Paulo. São Paulo. p.147-164. (Boletim, 41) 